\title{
FACTORS AFFECTING THE DISTRIBUTION OF SODIUM AND POTASSIUM IN AMPHIBIAN OOCYTES
}

\author{
by \\ K.B. IBRAHIM ${ }^{1 /}$ and D.A.T. DICK \\ University of Dundee \\ Dundee DD1 4HN, Scotland \\ "Present address: Department of Anatomy, \\ University of Mosul, Mosul, Iraq
}

Keywords: Sodium, potassium, chloride, amphibian oocyte, electron microprobe X-ray analysis, yolk platelets, cytoplasmic vesicles, nucleus

\begin{abstract}
The concentrations of sodium, potassium and chloride in the nucleus and cytoplasm of amphibian oocytes were measured by electron microprobe X-ray analysis. It was confirmed that sequestered sodium, which is not or only slowly exchanged with external lithium, lies entirely in the cytoplasm, in either the cytoplasmic vesicles or yolk platelets, most probably in the vesicles. This vesicular sodium may be involved in cellular transport of sodium. Potassium is most concentrated in the nucleus and is retained by a mechanism not dependent on the sodium-potassium exchange pump, most probably by binding to protein.
\end{abstract}

\section{INTRODUCTION}

Many studies have shown that $\mathrm{Na}$ and $\mathrm{K}$ are not equally concentrated in the nucleus and cytoplasm of amphibian oocytes. Although some older studies showed nuclear $\mathrm{Na}$ higher than cytoplasmic $(1,22)$, more recent studies have shown the nuclear Na concentration to be roughly equal to $(7,10)$ or less than $(5,24)$ the cytoplasmic $\mathrm{Na}$ concentration. On the other hand the nuclear $\mathrm{K}$ concentration has been reported to be much higher than the cytoplasmic (7). The purpose of the present studies was to provide further evidence in relation to the distribution of nuclear and cytoplasmic $\mathrm{Na}$ and $\mathrm{K}$ and any subfractions of them, and also to attempt to determine the factors governing their distribution.

Preliminary reports of some of this work have already been given $(11,17)$. 


\section{MATERIALS AND METHODS}

\subsection{Thick section studies}

\subsubsection{Preparation of specimen}

Rana temporaria were kept in a tank at room temperature and fed on maggots. The ovaries were removed immediately after killing the animal (between September and April) by decapitation, divided into pieces and kept in Ringer solution (7).

Measurements of $\mathrm{Na}$ and $\mathrm{K}$ were carried out by flame photometry (12). For microprobe analysis, sections were prepared by a freeze-drying method (7).

$23 \%$ solutions of bovine plasma albumin (Cohn fraction V) (Koch-Light) were used as a standard with varying amounts of $\mathrm{NaCl}$ and $\mathrm{KCl}$ added. The lowest levels of Na were obtained by dialysing albumin first against $\mathrm{KCl}$ to replace $\mathrm{Na}$ by $\mathrm{K}$ and then dialysing against water. Another standard also used was $24 \%$ bovine gamma globulin (Cohn fraction II) (Sigma) dissolved in varying concentrations of $\mathrm{KCl}$ with or without addition of $\mathrm{NaCl}$. The concentrations of $\mathrm{Na}$ and $\mathrm{K}$ in the standards were checked by flame photometry.

Preparation of freeze-dried sections from the standard for microprobe analysis was done in exactly the same way as for ovarian material.

\subsubsection{Electron microprobe $X$-ray analysis}

The sections were examined at $25 \mathrm{KeV}$ in a JEOL JSM-35 scanning electron microscope equipped with a horizontally-placed energy-dispersive $\mathrm{Si}$ ( $\mathrm{Li}$ ) X-ray detector (Kevex), to which was attached a pulse-height analyser and computer (Link System Ltd). The detector was 10 $\mathrm{mm}^{2}$ in area with a beryllium window of $8 \mu \mathrm{m}$ thick, transmitting approximately $40 \%$ of $\mathrm{Na}$ $\mathrm{X}$-rays. Specimen - to - detector distance was 2 $\mathrm{cm}$ and the takeoff angle was $45^{\circ}$. Full width at half maximum intensity was approximately 165 ev at $5.9 \mathrm{KeV}$. A scanned area of $3 \times 3 \mu \mathrm{m}$ and a counting time of $100 \mathrm{sec}$. were used. The condensers were defocused to give a large Gaussian spot size of $300 \mathrm{~nm}$ and an associated probe current of $10-15 \mathrm{nA}$. These gave a high count rate between $1000-2000$ counts per sec. with minimal damage to the specimen.

In order to collect X-rays emitted from the
Table I.

The windows set for measuring the peak and background for sodium, chlorine and potassium.

\begin{tabular}{lrr}
\hline & Window (ev) & No. of channels \\
\hline Background & $920-940$ & 2 \\
Peak Na & $980-1080$ & 6 \\
Background & $1120-1140$ & 2 \\
Peak Cl & $2560-2680$ & 7 \\
Background & $2920-3100$ & 10 \\
Peak K & $3240-3360$ & 7 \\
Background & $3800-3980$ & 10 \\
\hline
\end{tabular}

elements $\mathrm{Na}, \mathrm{K}$ and $\mathrm{Cl}$ present in the specimen a large window was set at the energy band of each element (Table I). Background X-rays were collected by using a separate window on either side of the peak so that any absorption of characteristic and background X-rays in the specimen was always equal and their ratio would be unaffected by absorption. The background count was measured for the same period of time as the count for peak. For $\mathrm{Na}$, the peak window has 6 channels and the two windows set for measuring the background have 2 channels each, and lie at the same distance from Na peak. The average background for subtraction from the peak was therefore obtained from the following formula:

$$
\left(B_{1}+B_{2}\right) \times 6 / 4
$$

where $B_{1}$ is the first background and $B_{2}$ is the second background.

For $\mathrm{K}$, both the first and second background windows have the same number of channels ( 10 channels each), but differ in their distance from the peak, owing to the interference of $\mathrm{K} \mathrm{K}_{\mathrm{b}}$ and $\mathrm{Ca} \mathrm{K}_{\mathrm{a}}$ peaks with the second background.

For calculation of the average background for $K$ the equation used was:

$$
\frac{P_{N}}{B_{a}}\left[{ }^{B_{1}}\left(\frac{\left(B_{2} \text { to } P\right)}{\left(B_{2} \text { to } P\right)+\left(P \text { to } B_{1}\right)}\right)+B^{+B_{2}}\left(\frac{\left(P \text { to } B_{1}\right)}{\left(B_{2} \text { to } P\right)+\left(P \text { to } B_{1}\right)}\right)\right]
$$

where $P_{N}=$ number of channels in peak window; $B_{a}=$ average number of channels in the first and second background windows; $\left(\mathrm{P}\right.$ to $\left.\mathrm{B}_{1}\right)=$ number of channels between the centres of the peak and first bacground windows; 


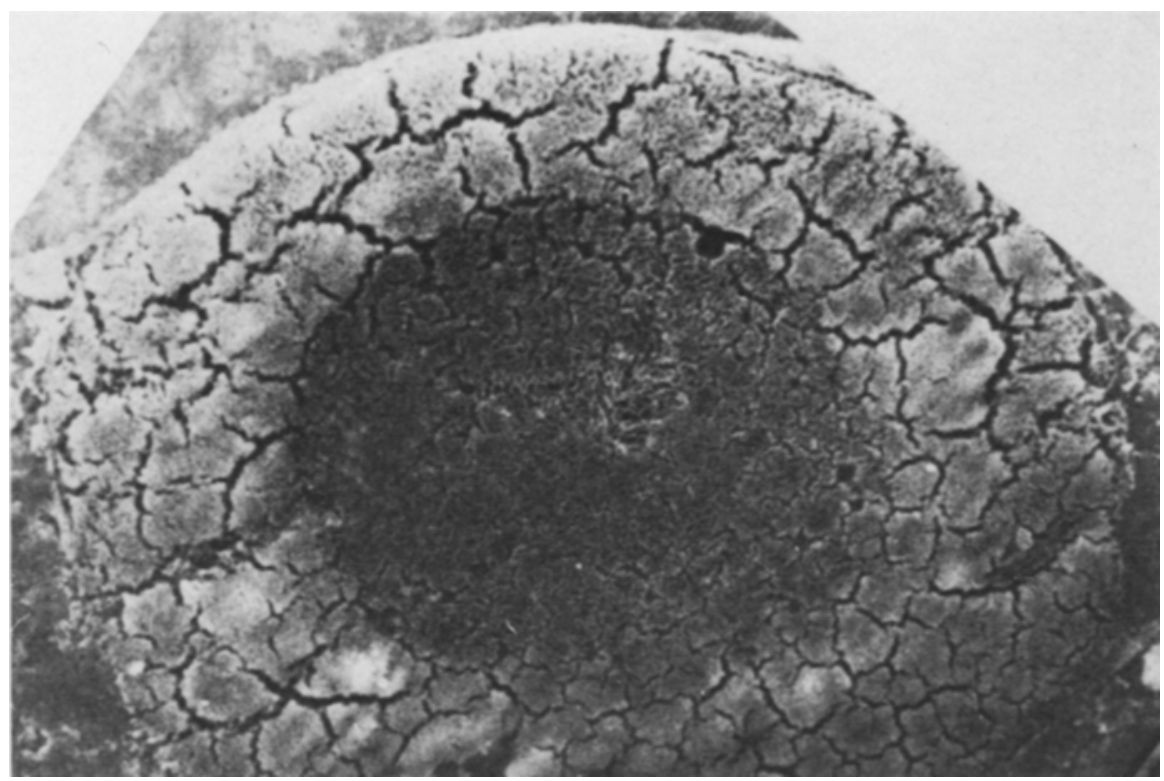

Figure 1. Scanning secondary electron micrograph of an unfixed cryostat section, $15 \mu \mathrm{m}$ thick, of an oocyte mounted and freeze-dried on a graphite stub. Cell and nuclear boundaries are visible.

$\left(B_{2}\right.$ to $\left.P\right)=$ number of channels between the centres of the peak and second background windows.

In the case of $\mathrm{Cl}$ it was difficult to set a window for measuring the first background owing to the closeness of the $\mathrm{S}$ peak to the $\mathrm{Cl}$ peak. So for measuring the average background of $\mathrm{Cl}$ only one background window $(2920-3100 \mathrm{eV})(10$ channels) was used (the same as the $B_{1}$ window for $K$ ). The ratio ( $R$ ) of the counts measured in the chloride window to those in the background window for a standard containing no chloride was used to obtain the background count to be subtracted from the chloride peak count for a chloride containing sample, thus:

Background subtracted $=R \times B_{1}=0.8616 B_{1}$.

\subsubsection{Treatment of data}

Analysis was made of elemental concentrations, both in cytoplasm and nucleus, of fresh oocytes and of oocytes kept in the solutions mentioned above. For analysis of oocytes kept in each solution three stubs were used. On each stub two sections of oocyte were selected. On each section six different areas from each of the cytoplasm and nucleus of each oocyte were analysed. So the total number of areas analysed was 36 on cytoplasm and 36 on nucleus.

The secondary electron scanning picture of an oocyte section (Figure 1) shows a clear visualization of the cell membrane and the nuclear boundary. The position of the cell membrane is revealed owing to the low solid content of the extracellular solution which virtually disappears on freeze-drying. The visualization of the nucleus is probably mainly due to the lower solid content of the nucleus as compared with the cytoplasm. The centres of the nuclear and cytoplasmic fields were generally selected for analysis. Since analysis of a section which lies near the periphery of the graphite stub produces high background due to back-scattered electrons which hit the column of the microscope, this was avoided by analysing the sections lying near the centre of the graphite stub. 
The concentrations of elements in the specimen were calculated by comparing the peak/ background $(\mathrm{P} / \mathrm{B})$ ratio with that of a known concentration of element in a standard. The $P / B$ ratios obtained from analysis of specimen were converted to elemental concentrations by using proportionality constants calculated from the calibration curves obtained from standards.

The basic equation used for calculation of concentrations of elements present in the specimen was given by CHANDLER (6) -

$$
\mathrm{C}_{\mathrm{x}}=\mathrm{K} \times\left(\mathrm{I}_{\mathrm{x}} / \mathrm{W}\right)
$$

where $C_{x}$ is the concentration of element $x . I_{x}$ is the characteristic $X$-ray intensity for element $X$. $\mathrm{W}$ is the background (continuum) produced from the specimen and measured as described above on either side of the energy $I_{x}$, and $K=$ (background)/(standard) is a quantitation constant parameter relating concentration to $\mathrm{P} / \mathrm{B}$ ratio and is obtained from standards. Owing to the low atomic number of all elements in the specimen, it was not found necessary to use a Z-correction, and since the specimen and standards were closely matched, absorption and fluorescence corrections were also unnecessary $(6,27)$. The concentration of the elements were thus obtained in $\mu \mathrm{mol} \times \mathrm{g}^{-1}$ dry solid in the sample area of the oocyte. These were converted into m-molex $(1 \text { cell water })^{-1}$ by means of estimates of the solid and water fraction of the nucleus and cytoplasm in oocytes of different sizes. The estimates used were those measured in toad oocytes of the same size since no data are available for frog oocytes (7)

\subsection{Thin section studies}

\subsubsection{Preparation of specimen (Bufa bufa)}

A single oocyte about $1 \mathrm{~mm}$ in diameter was dissected with iridectomy scissors, washed briefly with Li Ringer solution (to wash away the extracellular $\mathrm{Na}$ ), and placed in a tiny drop of methyl cellulose on a silver pin and quickly frozen in a nitrogen slush bath at a temperature of $-208^{\circ} \mathrm{C}(26)$.
Thin sections of $80-100 \mathrm{~nm}$ were cut on an LKB ultratome equipped with an LKB cryokit with specimen temperature set at $-120^{\circ} \mathrm{C}$ and a knife temperature of $-100^{\circ} \mathrm{C}$. The sections were cut onto a standard $45^{\circ}$ glass knife set at $10^{\circ}$ to the vertical and at a cutting speed of $5 \mathrm{~mm}$ per sec. The sections were allowed to dry in the cryochamber over three hours. After freeze-drying the sections were coated with a thin film $5 \mathrm{~nm}$ in thickness of pure carbon by vacuum evaporation and stored in a vacuum dessicator over silica gel.

Standards were frozen, sectioned, freezedried, mounted on nylon grids and coated with carbon in exactly the same way as oocyte specimens.

Thin sections were viewed and analysed without further treatment in an AEI EM6G transmission electron microscope with accelerating voltage of $100 \mathrm{KeV}$ and beam current $200 \mu \mathrm{A}$. $\mathrm{X}$-ray microprobe analysis was carried out with an energy dispersive Kevex-Link system similar to that used for thick section analysis. Full width at half maximum intensity was approximately $146 \mathrm{eV}$ at $5.9 \mathrm{KeV}$, the specimen-to-detector distance was $7 \mathrm{~cm}$, minimum probe diameter was $6 \mu \mathrm{m}$, and the time of analysis was 300 seconds. The specimens were placed horizontally and held in graphite inserts to reduce electron scattering and background reading. The channels set for collecting the characteristic $\mathrm{X}$-rays emitted from the elements $\mathrm{Na}$ and $\mathrm{K}$ and their corresponding backgrounds were the same as described for thick sections.

Electron microscopic pictures of our unfixed frozen-dried ultrathin sections showed an adequate resolution and clear visualization of yolk platelets but of no other organelles (Figures $2 a$ and $2 b$ ). The area of cytoplasm near the yolk platelets shows artefactual disruption either due to ice crystal formation or to sectioning areas of different consistency. The size of the yolk platelets being analysed is smaller than the probe size. In order to overcome this difficulty three or more large size yolk platelets which lay close

Figure 2. (a) High power electron micrograph of $0.1 \mu \mathrm{m}$ unfixed frozen-dried section of toad Bufo bufo oocyte. (Y) yolk platelet. The circle represents the size of the electron beam. The section is unstained. X 9,500. (b) High power electron micrograph of $0.1 \mu \mathrm{m}$ section of toad Bufo bufo oocyte prepared by the conventional technique of fixation, dehydration, embedding and staining. (Y) yolk platelets, (V) vesicle, (M) mitochondria. $\mathrm{X} 9,500$. 

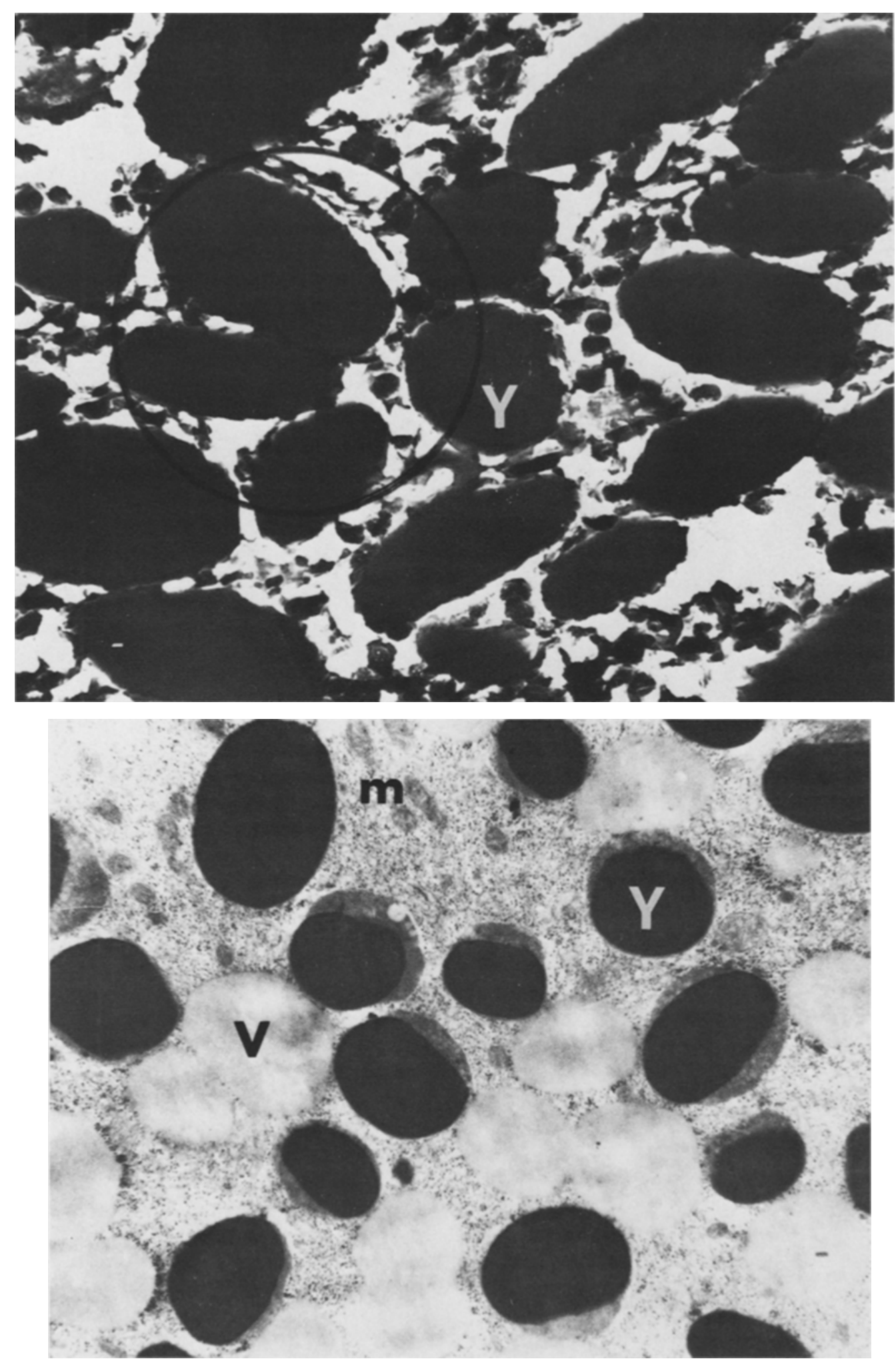


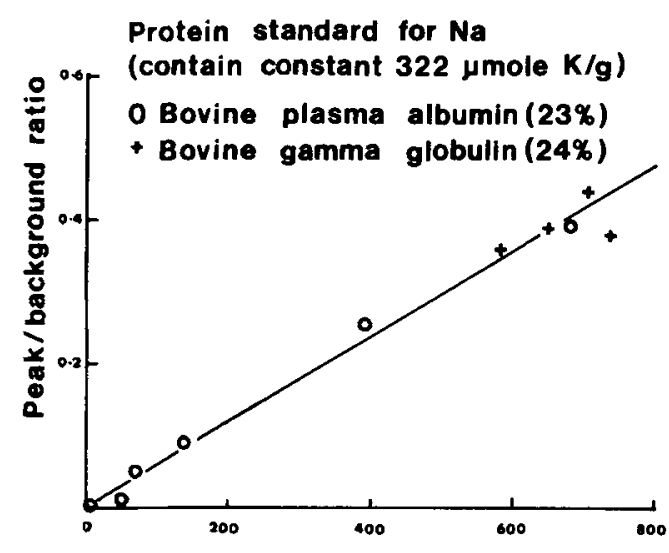

Na concentration ( $\mu$ mole $\mathrm{Na} / \mathrm{g}$ )

Figure 3. Linear relation between measured peak/ background ratio and concentration of $\mathrm{Na}$ for protein standards containing varying concentrations of $\mathrm{Na}$ (plus a constant $322 \mu$ mole $\mathrm{K} / \mathrm{g}$ ) protein (except for the three lowest points which had $139 \mu$ mole K/g) and varying concentrations of $\mathrm{Cl}$ ). Each point represents the mean of (15) observations. Vertical lines indicate \pm S.E. of the mean. Where not indicated S.E. is smaller than the symbol.

together were chosen so that the analysed area contained a minimum of cytoplasmic matrix (about one-third).

The X-ray spectrum obtained in a transmission electron microscope from analysis of a thin section includes, as well as characteristic peaks due to elements present in the specimen, also peaks (the largest one being the $\mathrm{Cu} \mathrm{K}_{\mathrm{a}}$ signal at $8047 \mathrm{eV}$ ) from the materials of the specimen holder, with an associated extraneous continuum and low-energy noise probably due to electrons reaching the detector. These extraneous signals and the associated continuum can be measured by collecting the spectrum generated with the beam passing through a grid hole containing no specimen and subtracting this from the spectrum resulting from analysis of the section.

Analyses were done both on areas containing yolk platelets and on areas of cytoplasm free of yolk platelets and the concentration of the element in each area was calculated from the peak/background ratio by using proportional constants obtained from the calibration curve of a standard as for thick section analysis.

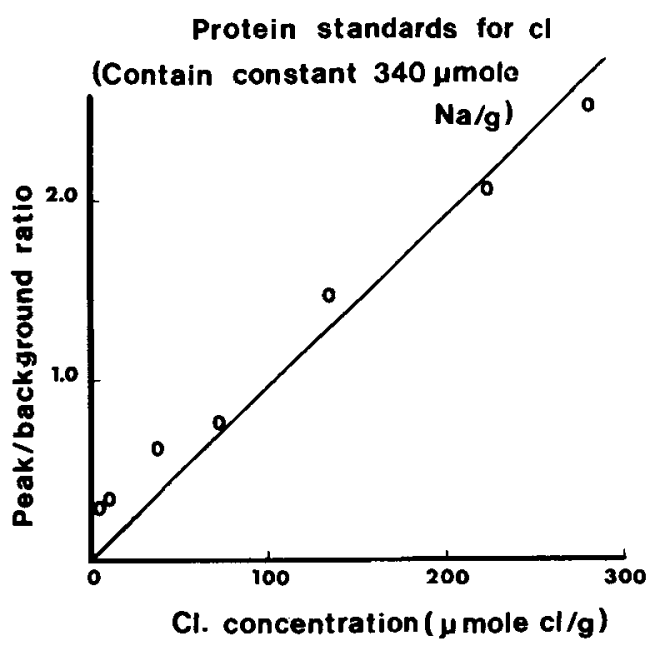

Figure 4. Linear relation between measured peak/ background ratio and concentration of $\mathrm{Cl}$ for bovine plasma albumin standards containing varying concentrations of $\mathrm{Cl}$ (plus a constant $340 \mu$ mole $\mathrm{Na} / \mathrm{g}$ albumin and varying concentrations of $\mathrm{K}$ ). Each point represents the mean of (15) observations. Vertical lines indicate \pm S.E. of the mean. Where not indicated S.E. is smaller than the symbol.

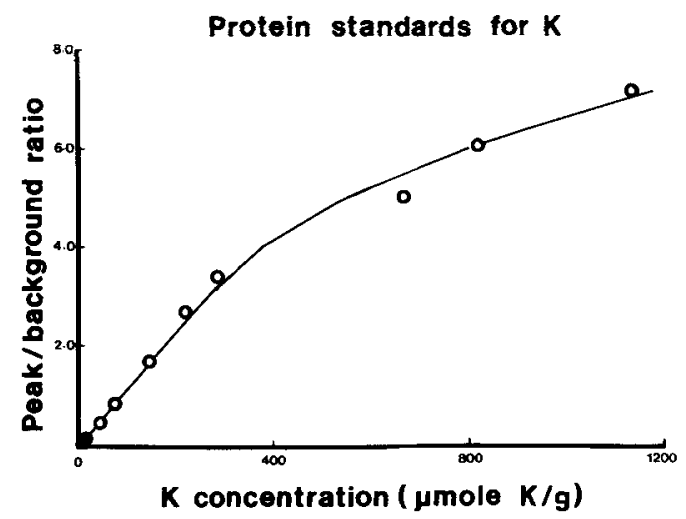

Figure 5. Quadratic correlation between measured peak/background ratio and concentration of $\mathrm{K}$ for bovine plasma albumin (23\%) standards containing varying concentrations of $K$ (plus a constant 340 $\mu$ mole $\mathrm{Na} / \mathrm{g}$ and varying concentrations of $\mathrm{Cl}$ ). Each point represents the mean of (15) observations. Vertical lines indicated \pm S.E. of the mean. Where not indicated S.E. is smaller than the symbol. 


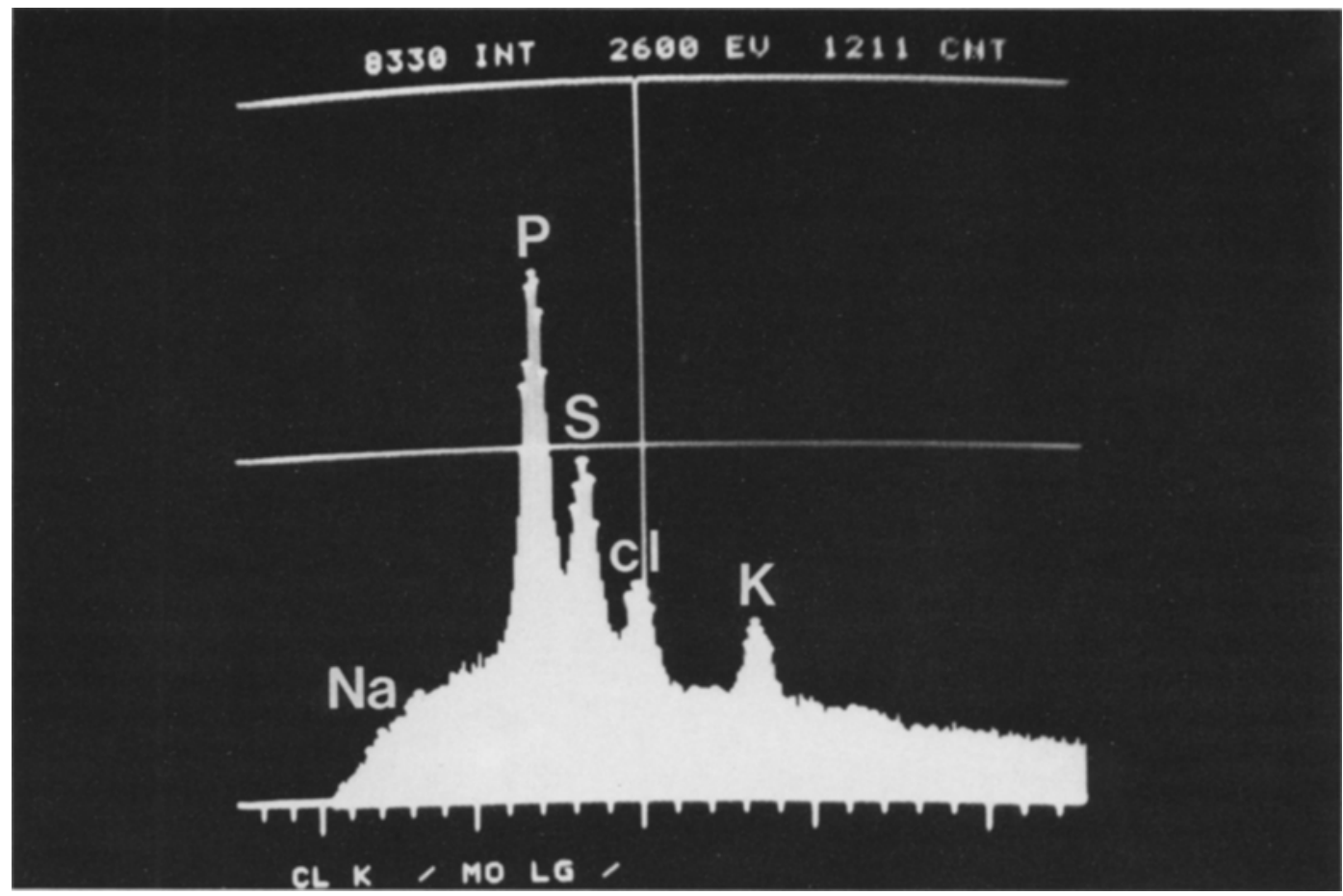

Figures 6-9. X-ray spectra photographed from the oscilloscope screen. The ordinate gives the number of counts for the energies shown on the abscissa in $\mathrm{KeV}$ (one unit $=0.2 \mathrm{KeV}$ ). The centre line marks the energy level characteristic of the chlorine $\mathrm{K}$-line $(2600 \mathrm{KeV})$. Note the characteristic peaks of elements superimposed upon the humped background which is due to white non-specific radiation.

Figure 6. X-ray spectrum of the cytoplasm from a $15 \mu \mathrm{m}$ frozen dried section of immature Rana temporaria oocyte freshly isolated in Ringer solution. Peaks for phosphorus, sulphur, chlorine and potassium are easily seen. Note a small peak for sodium.

\section{RESULTS}

\subsection{Thick sections}

\subsubsection{Measurements on standards}

The relation between $\mathrm{Na}, \mathrm{Cl}$ and $\mathrm{K}$ concentrations in $\mu$ molex(g solid $)^{-1}$ and peak/background ratio for standards made from $23 \%$ albumin and $24 \%$ globulin solutions are shown in Figures 3,4, 5. For $\mathrm{Na}$ and $\mathrm{Cl}$ the relation appears to be linear. For $\mathrm{K}$ the relation appears to be linear up to about $300 \mu$ molex $(\mathrm{g} \text { solid })^{-1}$, then it deviates from linearity at high $\mathrm{K}$ concentrations. Possible interference of $\mathrm{Mg}(1253 \mathrm{eV})$ and $\mathrm{Cu}(930 \mathrm{eV})$ with the $\mathrm{Na}$ peak $(1030 \mathrm{eV})$ was tested for but none was found.

\subsubsection{Measurement on oocytes}

The X-ray spectrum obtained from $15 \mu \mathrm{m}$ frozen-dried sections of the cytoplasm of immature Rana temporaria oocyte (Figure 6) is compared with that from a mature oocyte (Figure 8). The $\mathrm{K}$ peak is higher and Na peak is lower in immature than in mature oocytes, indicating a high $\mathrm{K}$ and a low Na content of the immature oocyte in agreement with previous flame photometer studies (4).

The X-ray spectrum obtained from $15 \mu \mathrm{m}$ frozen-dried sections of the nucleus of immature and mature Rana temporaria oocyte (Figures 7 , 9) is compared with that from the cytoplasm 


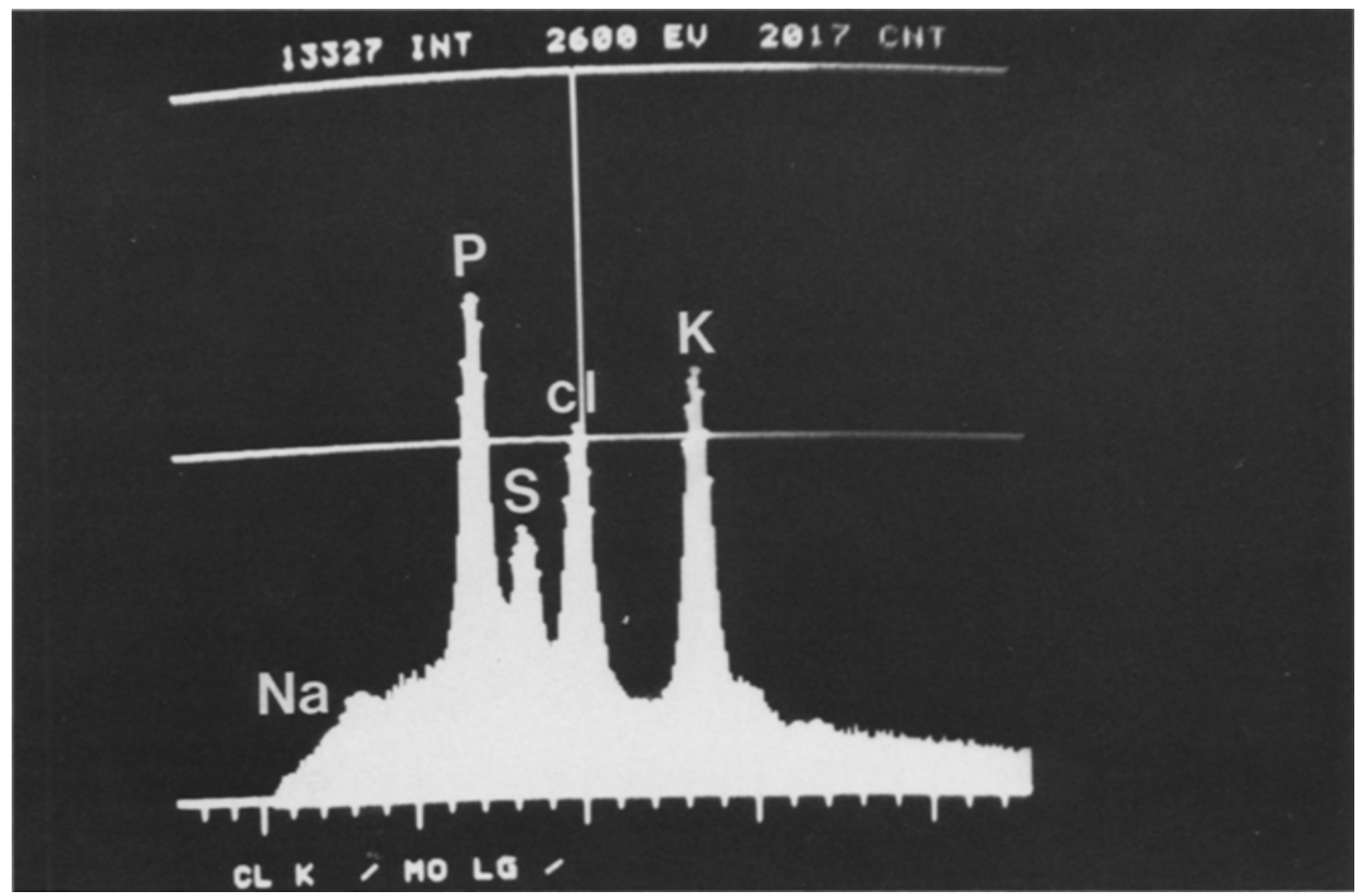

Figure 7. X-ray spectrum of the nucleus from a $15 \mu \mathrm{m}$ frozen-dried section of immature Rana temporaria oocyte freshly isolated in Ringer solution. Peaks for phosphorus, sulphur chlorine and potassium are easily seen. The small sodium peak indicates a low sodium content in the nucleus. The high potassium peak indicates a high potassium content in the nucleus.

(Figures 6,8). The K peak in the nucleus is higher than in the cytoplasm, indicating a higher $\mathrm{K}$ content in the nucleus than in the cytoplasm.

Repeated measurements of peak/background ratio in an area of oocyte cytoplasm showed no significant trend with time in the graphs for any of the elements. Measurements repeated at 15 $\mu \mathrm{m}$ intervals on passing inwards from the cell membrane show a uniform distribution of $\mathrm{Na}$ and $\mathrm{K}$ in the cytoplasm (see also DiCK (7)). Immediately inside the membrane the $\mathrm{Na}$ and $\mathrm{K}$ distribution shows no sign of loss into the extracellular space during freezing and freeze-drying.

The concentration of $\mathrm{Na}, \mathrm{K}$ and $\mathrm{Cl}$ was measured by microprobe analysis in Rana temporaria oocytes kept in Ringer solution 0, 5, 24 hours, in oocytes kept in Na-free Ringer solution (both $\mathrm{Li}$ and choline used as substitutes) for 5 and 24 hours, in oocytes kept in K-free Ringer solution for 24 hours, in oocytes kept in Ringer solution containing $10^{-3} \mathrm{M}$-ethacrynic acid for 24 hours, and in oocytes kept in Ringer solution containing $10^{-3} \mathrm{M}$-ouabain for 24 hours. Results are shown in Figures $10-15$.

Sodium concentration The mean nuclear concentration is significantly lower than the cytoplasmic concentration in cells exposed to Ringer solution for 0,5 and 24 hours ( $p<0.001$, $\mathrm{p}<0.01$ and $\mathrm{p}<0.001$, respectively). The nucleo/cytoplasmic ratios are 0.5 ( 0 hour), 0.7 ( 5 hours) and 0.4 (24 hours) (Figure 10).

When cells are exposed to Na-free Ringer ( $\mathrm{Li}$ or choline substituted for $\mathrm{Na}$ ), both the nuclear and cytoplasmic concentrations tend to be lower. However, the reduction in nuclear concentration is greater than that in the cytoplasmic concentration. The nucleo/cytoplasmic ratio in cells exposed to Li-substituted Ringer for 5 


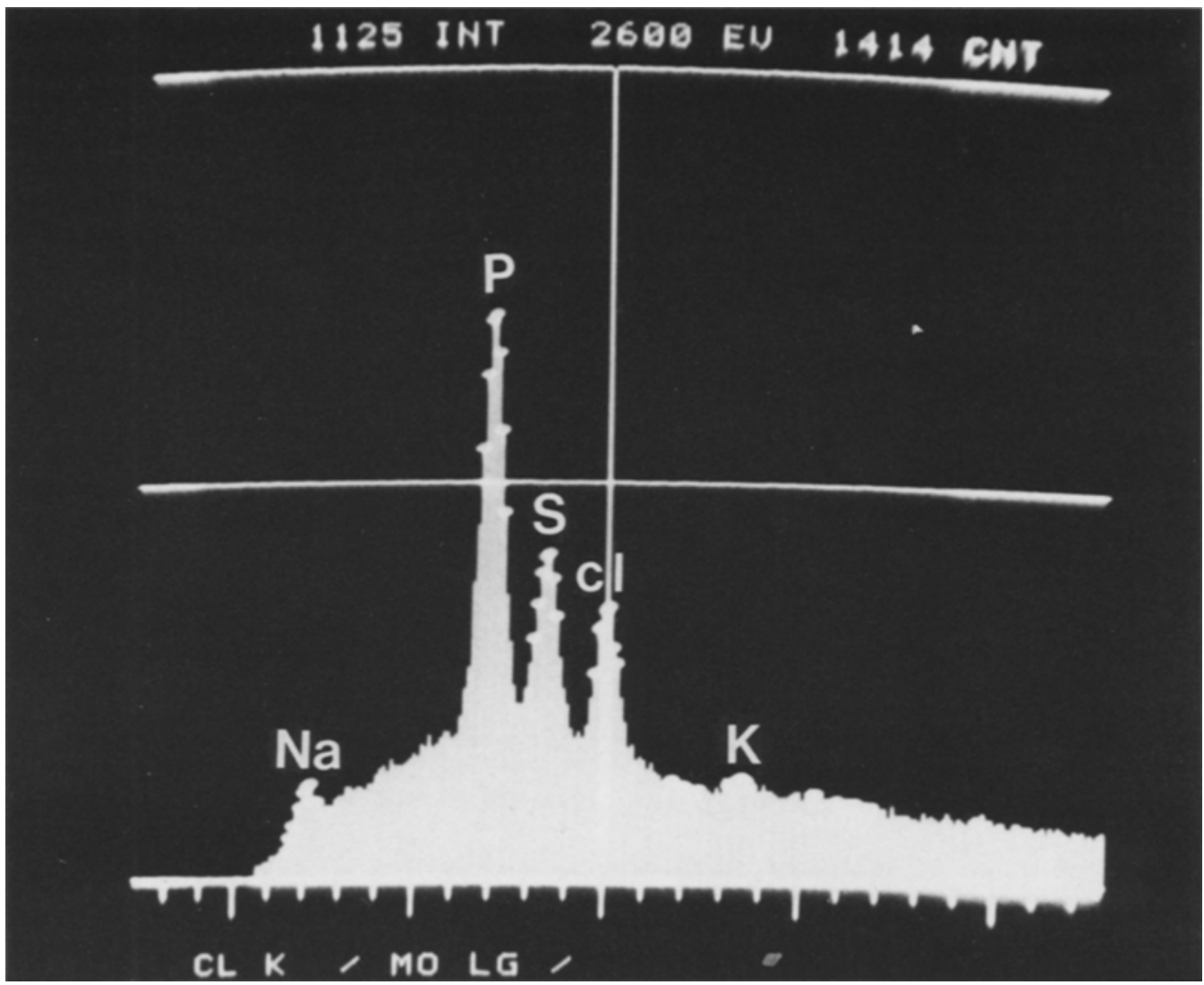

Figure 8. X-ray spectrum of the cytoplasm from a $15 \mu \mathrm{m}$ frozen dried section of mature Rana temporaria oocyte freshly isolated in Ringer solution. Peaks for sodium, phosphorus, sulphur and chlorine are easily seen. The peak for potassium is very small indicating a low content of potassium in the mature oocyte.

hours is 0.05 ( 5 hours). While in cells exposed to choline-substituted Ringer for 5 hours the ratio is 0.01 (Figure 10).

When cells are exposed to K-free Ringer solution for 24 hours both the nuclear and cytoplasmic $\mathrm{Na}$ concentrations increase and become significantly higher than Na concentrations in cells kept in Ringer solution for 24 hours ( $p<0.001$ and $p<0.05$, respectively). At the same time there is now no significant difference between the nuclear and cytoplasmic concentration (Figure 11).

After treatment of the cells with sodiumpump inhibitors (ethacrynic acid or ouabain) the $\mathrm{Na}$ concentration increases, both in the nucleus and cytoplasm. The evidence suggests that (especially in the case of cells exposed to ouabain which does not penetrate the cell membrane) the change in nuclear level of $\mathrm{Na}$ merely reflects the change in cytoplasmic level (Figure 11).

When overall $\mathrm{Na}$ concentrations in oocytes are calculated from the known volumes and water contents of nucleus and cytoplasm and are compared with the $\mathrm{Na}$ concentrations obtained in oocytes by flame photometry, it is found in most experiments that the overall $\mathrm{Na}$ concentrations are higher than the concentrations of $\mathrm{Na}$ obtained by flame photometry. The overall mean ratio is $1.5 \pm 0.13$ (S.E.) and is signi- 


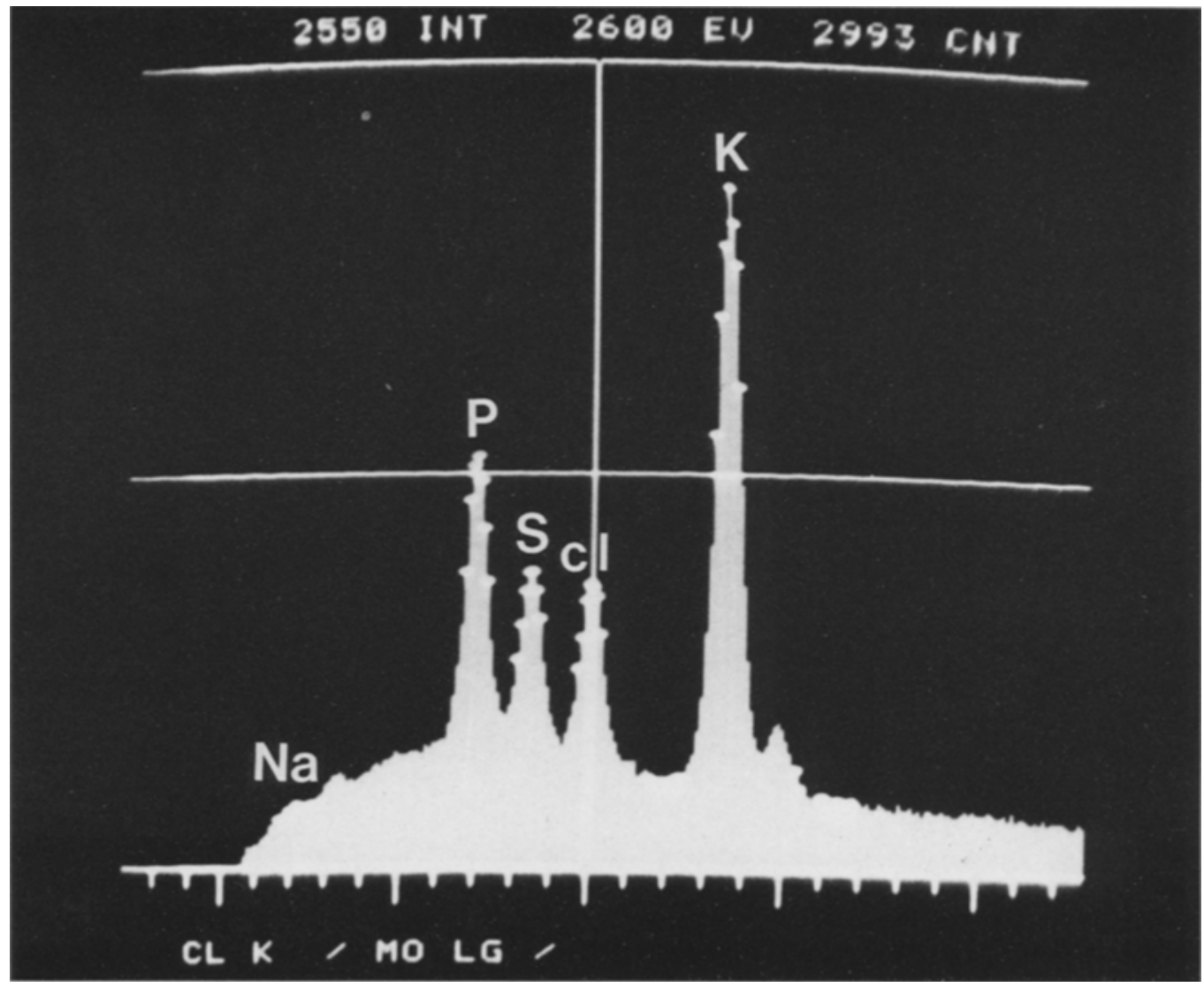

Figure 9. X-ray spectrum of the nucleus from a $15 \mu \mathrm{m}$ frozen-dried section of mature Rana temporaria oocyte freshly isolated in Ringer solution. Peaks for phosphorus, sulphur, chlorine and potassium are easily seen. The small sodium peak indicates a low sodium content in the nucleus. The high potassium peak indicates a high potassium content in the nucleus.

ficantly different from $1.00(p<0.001)$.

Potassium concentration. (Figures 12 and 13). The most important finding is that the nuclear $\mathrm{K}$ concentration is significantly higher than the cytoplasmic level in all solutions. The values of the nucleo/cytoplasmic ratio vary between 2.7 to 5.2. The difference is highest in cells exposed to Ringer solution containing $10^{-3} \mathrm{M}$ ethacrynic acid. In these the ratio of nuclear $\mathrm{K}$, $135 \pm 6.4$ (S.E. of mean) (36) m-mole/l. $\mathrm{H}_{2} \mathrm{O}$, to cytoplasmic $\mathrm{K}, 26 \pm 4.2$ (S.E. of mean) (36) $\mathrm{m}$-mole/l. $\mathrm{H}_{2} \mathrm{O}$ is 5.2 (Figure 13). The difference is lowest in cells exposed to Li-Ringer for 5 hours. In these the ratio of nuclear $\mathrm{K}, 142 \pm 6.3$ (S.E. of mean) (72) m-mole/l. $\mathrm{H}_{2} \mathrm{O}$, to cytoplasmic K, $53 \pm 3.6$ (S.E. of mean) (72) m-mole/l. $\mathrm{H}_{2} \mathrm{O}$, is 2.7 (Figure 12).
These results reveal that in terms of concentration, the dominant nuclear cation measured in situ is $\mathrm{K}$ rather than $\mathrm{Na}$.

The overall $\mathrm{K}$ concentrations in the cell as measured by microprobe analysis (calculated by means of the known volumes and water contents of nucleus and cytoplasm) are compared with $\mathrm{K}$ concentrations estimated by flame photometry. The overall mean ratio of the microprobe analysis estimate of $\mathrm{K}$ to the flame photometry estimate is $1.23 \pm 0.10$ (SEM) and is significantly different from $1.0(p<0.05)$.

Chloride concentration. (Figures 14 and 15). The nuclear concentration of $\mathrm{Cl}$ is lower than that of the cytoplasm in all solutions. This suggests the presence of fixed negative sites, probably on nuclear proteins. The overall mean 


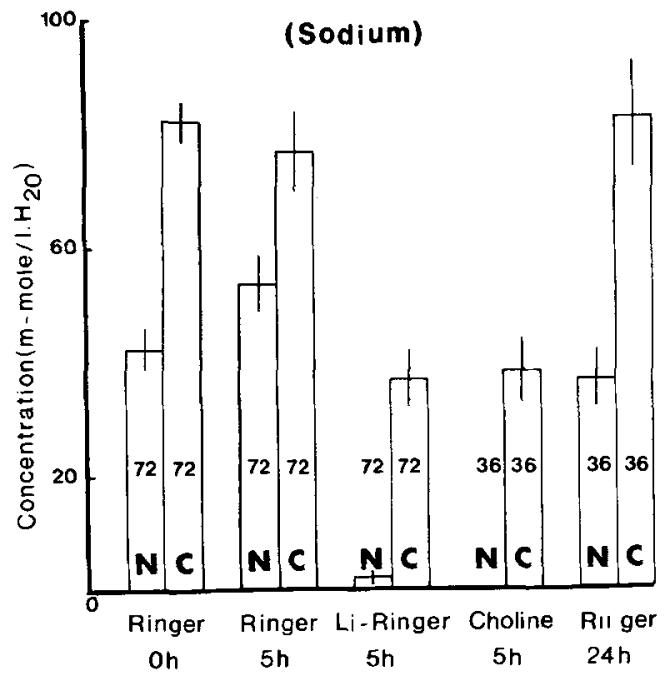

Figure 10. Histogram of the nuclear and cytoplasmic Na concentrations measured by electron microprobe $\mathrm{X}$-ray analysis from Rana temporaria oocytes kept in Ringer (0, 5, 24 hours), Li-Ringer (5 hours) and choline Ringer ( 5 hours) solutions. Bars indicate \pm S.E. of the overall mean. The figures inside the columns represent the number of observations. $(\mathrm{N})$ nucleus, (C) cytoplasm. The nuclear concentration is significantly lower than that of the cytoplasm in all solutions but much lower in $\mathrm{Li}$ and choline Ringer solutions.

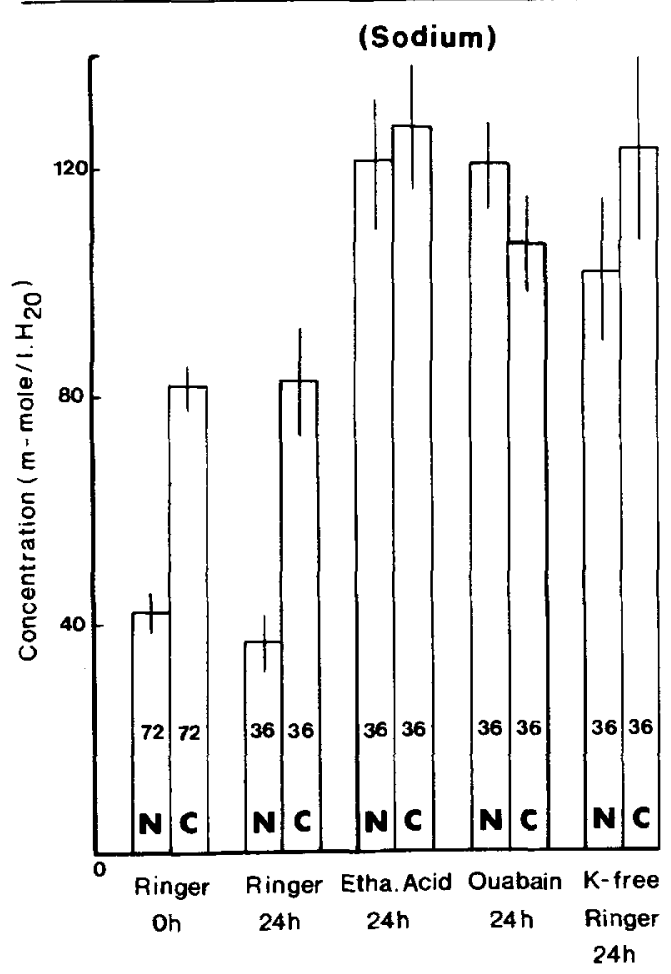

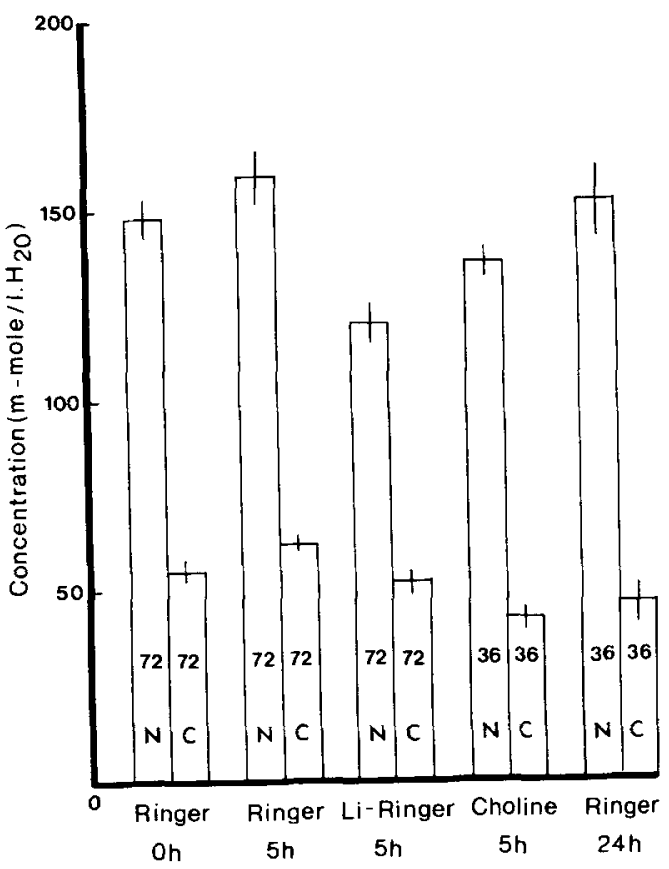

Figure 12. Histogram of the nuclear and cytoplasmic $\mathrm{K}$ concentrations measured by electron microprobe $\mathrm{X}$-ray analysis from Rana temporaria oocytes kept in Ringer (0, 5, 24 hours), Li-Ringer ( 5 hours) and choline Ringer ( 5 hours) solutions. Bars indicate \pm S.E. of the overall mean. The figures inside the columns represent the number of observations. $(\mathrm{N})$ nucleus, (C) cytoplasm. The nuclear concentration is significantly higher than that of the cytoplasm in all solutions.

Figure 11. Histogram of the nuclear and cytoplasmic $\mathrm{Na}$ concentrations measured by electron microprobe $\mathrm{X}$-ray analysis from Rana temporaria oocytes kept in Ringer $\left(0,24\right.$ hours), Ringer containing $10^{-3} \mathrm{M}$ ethacrynic acid (24 hours), Ringer containing $10^{-3} \mathrm{M}$ ouabain ( 24 hours) and K-free Ringer ( 24 hours) solutions. Bars indicate \pm S.E. of the overall mean. The figures inside the columns represent the number of observations. (N) nucleus, (C) cytoplasm. Both the nuclear and cytoplasmic concentrations in oocytes kept in Ringer solution containing ethacrynic acid or ouabain and in $\mathrm{K}$-free Ringer solution are significantly higher than its concentration in oocytes kept in Ringer solution ( 24 hours). 

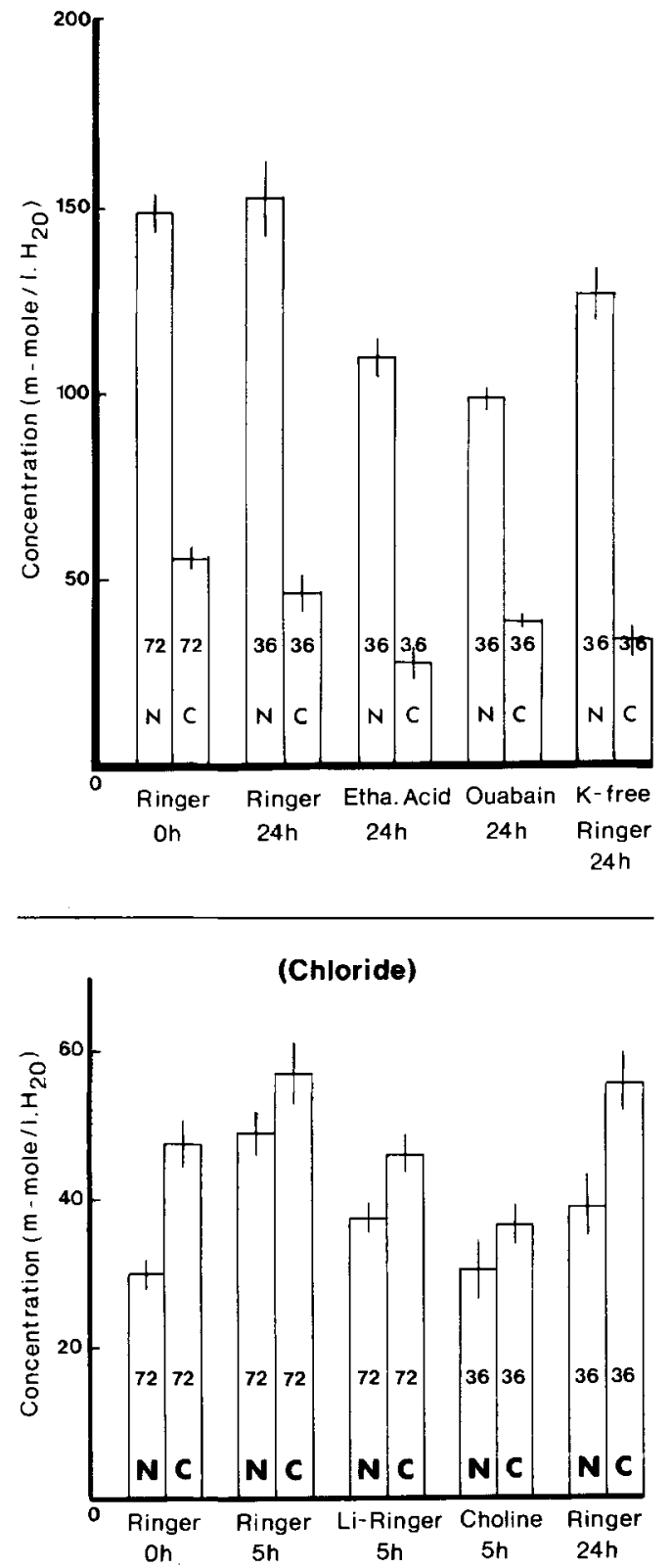

Figure 14. Histogram of the nuclear and cytoplasmic $\mathrm{Cl}$ concentrations measured by electron microprobe analysis from Rana temporaria oocytes kept in Ringer $(0,24$ hours), Li-Ringer (24 hours) and choline Ringer ( 24 hours) solutions. Bars indicate \pm S.E. of the overall mean. The figures inside the columns represent the number of observations. (N) nucleus, (C) cytoplasm. The nuclear concentration is significantly lower than its concentration in the cytoplasm in all solutions except in choline Ringer where the nuclear concentrations is lower but not significantly different from the cytoplasmic concentrations.
Figure 13. Histogram of the nuclear and cytoplasmic $\mathrm{K}$ concentrations measured by electron microprobe analysis from Rana temporaria oocytes kept in Ringer ( 0,24 hours), Ringer containing $10^{-3} \mathrm{M}$ ethacrynic acid (24 hours), Ringer containing $10^{-3} \mathrm{M}$ ouabain (24 hours) and K-free Ringer ( 24 hours) solutions, Bars indicate \pm S.E. of the overall mean. The figures inside the columns represent the number of observations. (N) nucleus, (C) cytoplasm. The nuclear concentration is significantly higher than that of the cytoplasm in all solutions.

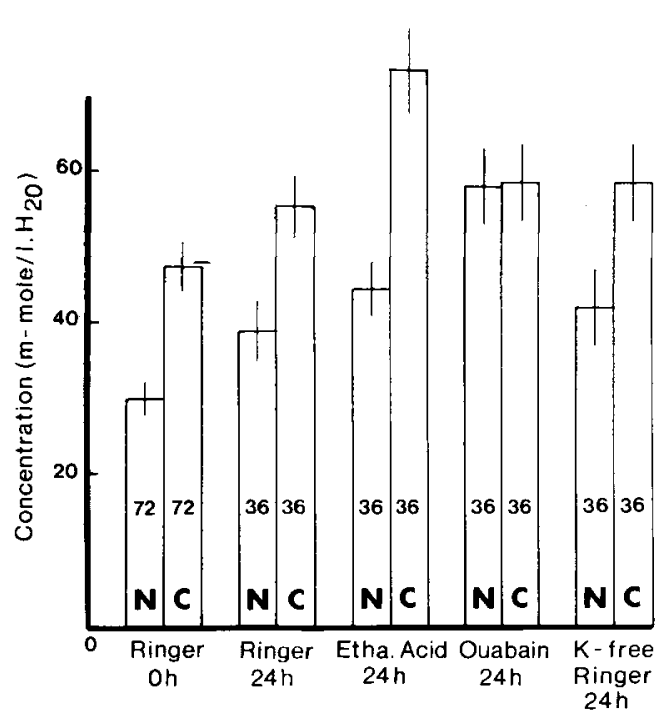

Figure 15. Histogram of the nuclear and cytoplasmic $\mathrm{Cl}$ concentrations measured by electron microprobe $\mathrm{X}$-ray analysis from Rana temporaria oocytes kept in Ringer (0, 24 hours), Ringer containing $10^{-3} \mathrm{M}$ ethacrynic acid (24 hours), Ringer containing $10^{-3} \mathrm{M}$ ouabain ( 24 hours), and K-free Ringer (24 hours) solutions. Bars indicate \pm S.E. of the overall mean. The figures inside the columns represent the number of observations. (N) nucleus, (C) cytoplasm. The nuclear concentration is significantly lower than its concentration in the cytoplasm in all solutions except in ouabain where the nuclear concentration is not significantly different from the cytoplasmic concentration. 
of $\mathrm{Cl}$ concentration in the whole cell (calculated by means of the known volumes and water contents of nucleus and cytoplasm) of all experiments is $52.1 \pm 2.8(\mathrm{SEM})(78) \mathrm{mmol} / \mathrm{l} . \mathrm{H}_{2} \mathrm{O}$ (Figure 14).

\subsection{Thin sections}

\subsubsection{Measurement on standards}

The relation between $\mathrm{Na}$ and $\mathrm{K}$ concentra-

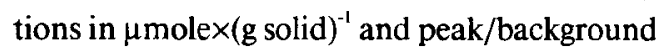
ratio for standards made from $23 \%$ albumin and $24 \%$ globulin solutions are shown in Figures 16 and 17. For both $\mathrm{Na}$ and $\mathrm{K}$ the relation appears to be linear.

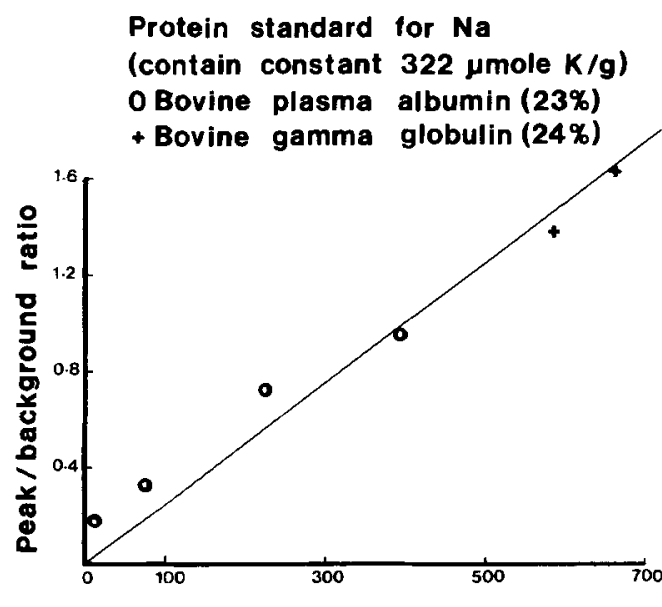

Na concentration ( $\mu$ mole $\mathrm{Na} / \mathrm{g}$ )

Figure 16. Linear relation between peak/background ratio (measured from $0.1 \mu \mathrm{m}$ frozen-fried sections) and concentration of $\mathrm{Na}$ for protein standards in thin sections containing varying concentrations of $\mathrm{Na}$ (plus a constant $322 \mu$ mole $\mathrm{K} / \mathrm{g}$ protein (except for the two lowest points which had $139 \mu \mathrm{mole} \mathrm{K} / \mathrm{g}$ ) and varying concentrations of $\mathrm{Cl}$. Each point represents the mean of (15) observations. Vertical lines indicate \pm S.E. of the mean. Where not indicated the S.E. is smaller than the symbol.

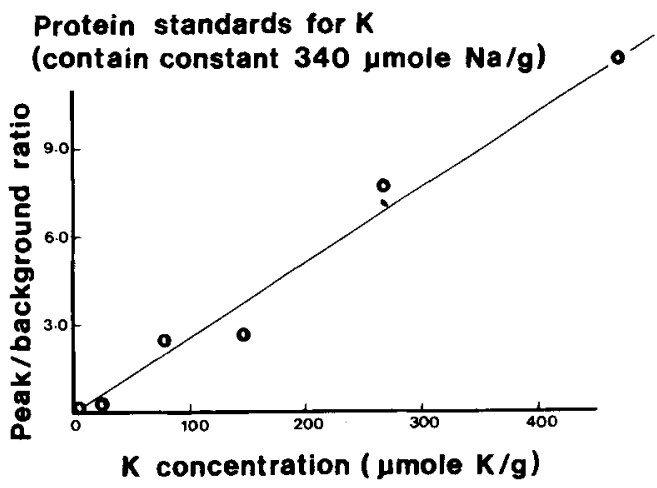

Figure 17. Linear relation between peak/background ratio (measured from $0.1 \mu \mathrm{m}$ frozen dried sections) and concentration of $\mathrm{K}$ for albumin standards (23\%) in thin sections containing varying concentrations of $\mathrm{K}$ (plus a constant $340 \mu$ mole $\mathrm{Na} / \mathrm{g}$ albumin and varying concentrations of $\mathrm{Cl}$ ). Each point represents the mean of (15) observations. Vertical lines indicate \pm S.E. of the mean. Where not indicated the S.E. is smaller than the symbol.

\subsubsection{Measurement on oocytes (Bufo bufo)}

The X-ray spectrum obtained from a cytoplasmic area containing no yolk platelets in an ultrathin frozen-dried section (Figure 19) is compared with that from an area of cytoplasm containing yolk (Figure 18). The sodium peak in the cytoplasmic area is higher than in the yolk area indicating a higher sodium concentration in the cytoplasm as compared with yolk platelets.

The peak/background ratios of $\mathrm{Na}$ and $\mathrm{K}$ in cytoplasm and yolk platelets are shown in Table II. The data show that the peak/background ratio for both $\mathrm{Na}$ and $\mathrm{K}$ in the cytoplasmic areas is higher than in the yolk areas. The peak/background ratios of $\mathrm{Na}$ and $\mathrm{K}$ in cytoplasm are $(0.45 \pm 0.03$ and $5.03 \pm 0.36)$ (S.E. of mean) $(\mathrm{n}=21)$, respectively, and in yolk are $(0.11 \pm$ 0.01 and $2.31 \pm 0.1)$ (S.E. of mean) $(n=21)$, respectively.

The concentrations of $\mathrm{Na}$ and $\mathrm{K}$ in oocytes per litre of wet tissue and per litre of water (Table II) were calculated by means of known solid and water fractions of the cytoplasm (7) and of yolk platelets, $(30 \%$ water (29)). The $\mathrm{Na}$ concentration (m-mole/l wet tissue) in cyto- 


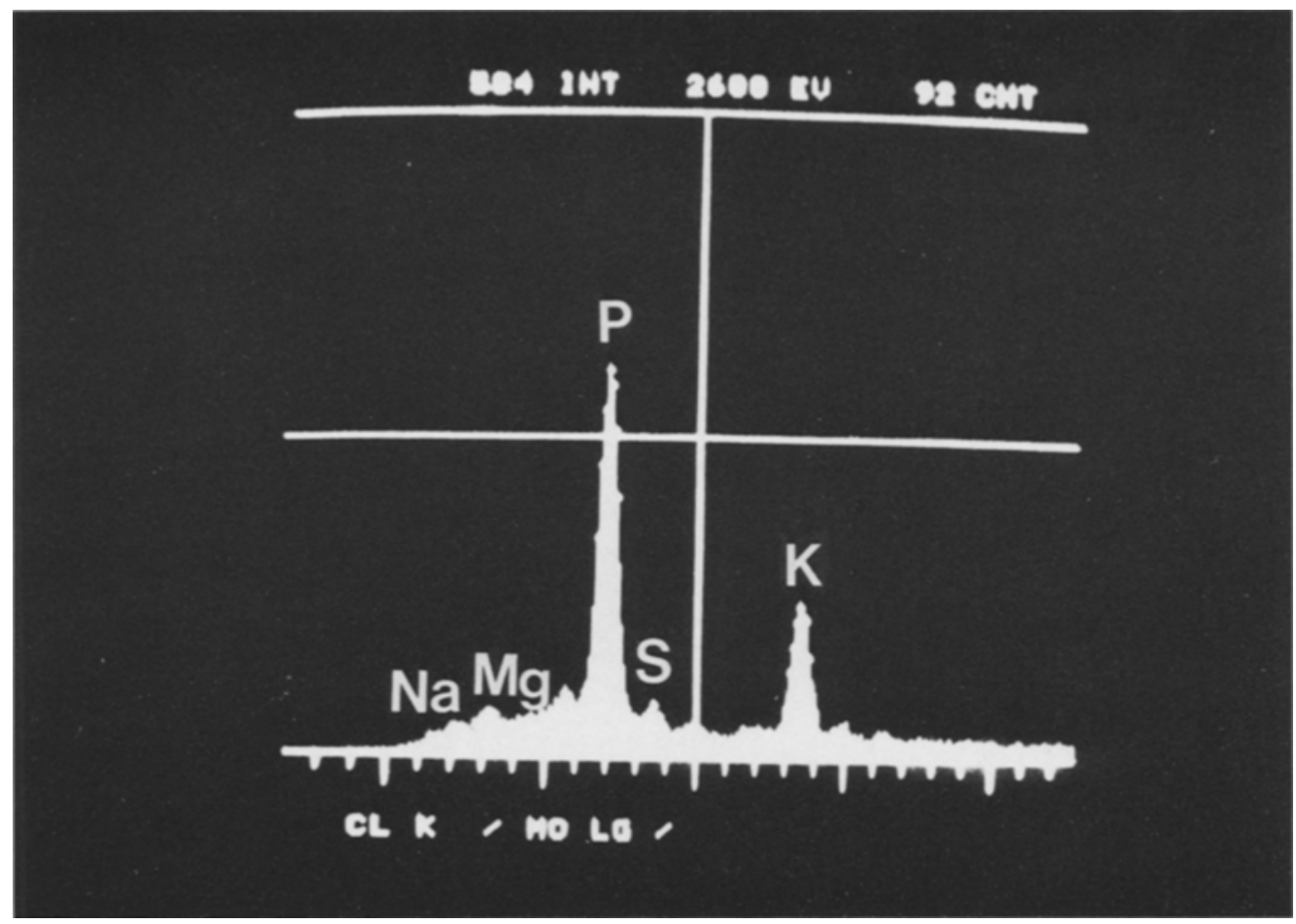

Figure 18. X-ray spectrum of the yolk platelets from $0.1 \mu \mathrm{m}$ unfixed frozen-dried section of toad Bufo bufo oocyte freshly isolated in Ringer solution. Peaks for magnesium, phosphorus, and potassium are easily seen. Note small peaks for sodium, silicon (arrow) (a contaminant) and sulphur. The small peak for sodium shows a low sodium contant in the yolk platelets.

plasm is higher than its concentration in yolk platelets. The mean concentration of cytoplasmic $\mathrm{Na}$ is $50.1 \pm 3.6$ (S.E. of mean) $(\mathrm{n}=21)$ $\mathrm{m}$-mole/l wet tissue and in yolk is $34.9 \pm 4.1$ (S.E. of mean) $(\mathrm{n}=21) \mathrm{m}$-mole 1 wet tissue. The mean of the ratios of yolk/cytoplasm for $\mathrm{Na}$ in the cells examined is $0.72 \pm 0.07$ ( $\mathrm{n}=$ 21 ), and is significantly different from 1.00 $(\mathrm{p}<0.001)$.

The $\mathrm{K}$ concentration (m-mole/l wet tissue) in cytoplasm is lower than in the yolk platelets. The mean concentration of cytoplasmic K, 58.6 \pm 4.3 (S.E. of mean) $(n=21) \mathrm{m}-\mathrm{mole} / \mathrm{l}$ wet tissue, and in yolk is $76.4 \pm 3.3$ (S.E. of mean) $(\mathbf{n}=21) \mathrm{m}$-mole/l wet tissue. The mean of the ratios of yolk/cytoplasm for $K$ in the cells examined is $1.66 \pm 0.23(\mathrm{n}=21)$, and is significantly different from $1.00(p<0.01)$.

Table II shows the concentrations of $\mathrm{Na}$ and $\mathbf{K}$ in the cytoplasm and yolk platelet calculated in $\mathrm{m}$-mole per litre of water. The mean $\mathrm{Na}$ concentration of cytoplasm is $64.6 \pm 4.8$ (S.E. of mean) $(\mathrm{n}=21)$, and in the yolk is $138.2 \pm$ 16.2 (S.E. of mean) $(n=21)$. The mean $K$ concentration of cytoplasm is $75.3 \pm 5.5$ (S.E. of mean $(n=21)$, and in the yolk is $303.0 \pm$ 13.3 (S.E. of mean) $(n=21)$. The mean concentration of $\mathrm{Na}$ and $\mathrm{K}$ per litre of water in the cytoplasm is thus significantly lower than their concentrations in the yolk platelets $(\mathrm{p}<0.001)$. These estimates of concentration depend heavily on the figure of $0.3 \mathrm{ml} \mathrm{H} \mathrm{H}_{2} \mathrm{O}$ per ml yolk platelets taken for water content of yolk platelets, and are much more sensitive to the accuracy of the water concentration estimation used than the concentrations calculated per litre of wet tissue.

It must be noted that the amount of cytoplasm (about one-third) in the yolk areas has been ignored, so that the true differences between yolk and cytoplasm are probably greater than those calculated above. 


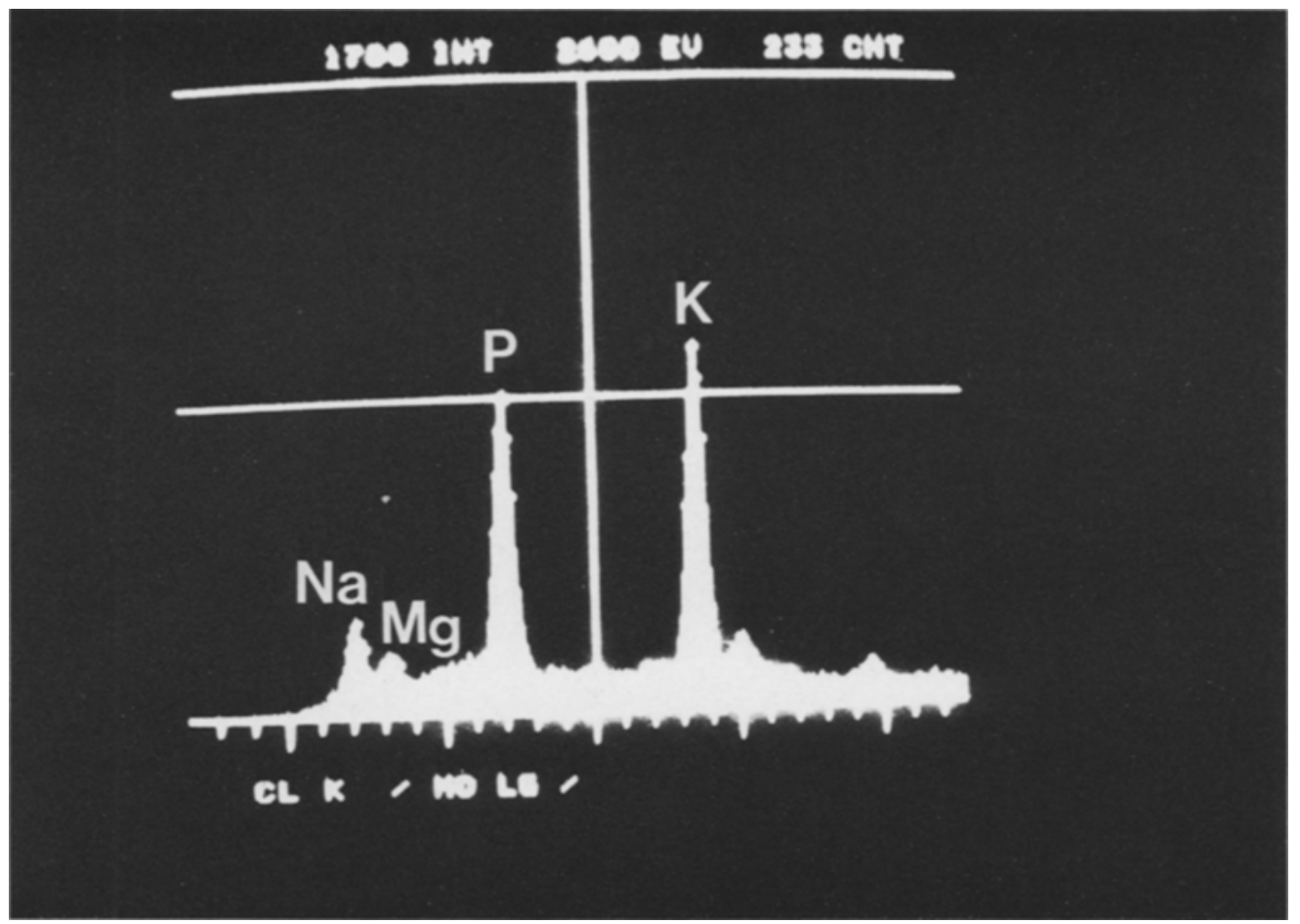

Figure 19. X-ray spectrum of the cytoplasm (free of yolk platelets) from $0.1 \mu \mathrm{m}$ unfixed frozen-dried section of toad Bufo bufo oocyte freshly isolated in Ringer solution. Peaks for sodium, magnesium, phosphorus, and potassium are easily seen.

\section{Table II.}

Peak/background ratio of $\mathrm{Na}$ and $\mathrm{K}$ in the cytoplasm and yolk platelets of toad Bufo bufo oocytes freshly isolated in Ringer solution.

\begin{tabular}{llll}
\hline & & \multicolumn{2}{c}{ Peak/background ratio } \\
\cline { 2 - 3 } $\begin{array}{l}\text { Cyto } \\
\text { plasm }\end{array}$ & $\begin{array}{l}\text { Cell diameter } \\
(\mu \mathrm{m})\end{array}$ & $\begin{array}{l}\mathrm{Na} \\
\text { mean } \pm \text { S.E. }\end{array}$ & $\begin{array}{l}\mathrm{K} \\
\text { mean }+ \text { S.E. }\end{array}$ \\
\hline 1 & 975 & $0.50 \pm 0.03(6)^{*}$ & $2.83 \pm 0.36(6)^{*}$ \\
2 & 957 & $0.60 \pm 0.10(5)$ & $6.84 \pm 0.32(5)$ \\
3 & 860 & $0.31 \pm 0.10(5)$ & $5.28 \pm 1.15(5)$ \\
4 & 874 & $0.38 \pm 0.05(5)$ & $5.15 \pm 0.29(5)$ \\
Overall mean $^{++}$ & & $0.45 \pm 0.03(21)$ & $5.03 \pm 0.36(21)$ \\
Yolk & & & \\
1 & & & $2.56 \pm 0.02(6)$ \\
2 & 975 & $0.14 \pm 0.02(6)$ & $1.84 \pm 0.34(5)$ \\
3 & 957 & $0.17 \pm 0.02(5)$ & $2.01 \pm 0.27(5)$ \\
4 & 860 & $0.03 \pm 0.01(5)$ & $2.83 \pm 0.39(5)$ \\
Overall mean $^{++}$ & 874 & $0.10 \pm 0.004(5)$ & $2.31 \pm 0.1(21)$ \\
\hline
\end{tabular}

* Number of observations

+ Cell diameter was the mean of a batch of similar cells from which the measured cell was taken.

${ }^{++}$Calculated from all measurements from all cells taken together. 
Table II. (cont.)

$\mathrm{Na}$ and $\mathrm{K}$ concentrations (m-mole/ $\mathrm{l}$ wet tissue) measured by microprobe analysis in the cytoplasm and yolk platelets of toad Bufo bufo oocytes freshly isolated in Ringer solution.

\begin{tabular}{|c|c|c|c|}
\hline \multirow[b]{2}{*}{$\begin{array}{l}\text { Cyto } \\
\text { plasm }\end{array}$} & \multirow[b]{2}{*}{$\begin{array}{l}\text { Cell diameter }{ }^{+} \\
(\mu \mathrm{m})\end{array}$} & \multicolumn{2}{|c|}{ Concentration in individual cells } \\
\hline & & $\begin{array}{l}\mathrm{Na} \\
\text { mean } \pm \text { S.E. }\end{array}$ & $\begin{array}{l}\mathrm{K} \\
\text { mean } \pm \text { S.E. }\end{array}$ \\
\hline 1 & 975 & $58.7 \pm 3.9(6)$ & $34.9 \pm 4.5(6)$ \\
\hline 2 & 957 & $68.6 \pm 11.2(5)$ & $82.9 \pm 3.9(5)$ \\
\hline 3 & 860 & $32.9 \pm 10.9(5)$ & $58.6 \pm 12.8(5)$ \\
\hline 4 & 874 & $40.1 \pm 5.3(5)$ & $57.8 \pm 3.2(5)$ \\
\hline Overall mean $^{++}$ & & $50.1 \pm 3.6(21)$ & $58.6 \pm 4.3(21)$ \\
\hline \multicolumn{4}{|l|}{ Yolk } \\
\hline 1 & 975 & $45.1 \pm 5.8(6)$ & $84.6 \pm 6.7(6)$ \\
\hline 2 & 957 & $52.8 \pm 7.6(5)$ & $60.8 \pm 11.1(5)$ \\
\hline 3 & 860 & $10.1 \pm 3.2(5)$ & $66.5 \pm 8.9(5)$ \\
\hline 4 & 874 & $31.4 \pm 1.7(5)$ & $93.6 \pm 12.9(5)$ \\
\hline Overall mean ${ }^{++}$ & & $34.9 \pm 4.1(21)$ & $76.4 \pm 3.3(21)$ \\
\hline
\end{tabular}

All concentrations in m-mole/l wet tissue \pm S.E. of mean (no. of observations).

+ Cell diameter was the mean of a batch of similar cells from which the measured cell was taken

++ Calculated from all the concentration measurement from all cells taken together.

Table II. (cont.)

$\mathrm{Na}$ and $\mathrm{K}$ concentrations ( $\mathrm{m}$-mole/ $/ \mathrm{H}_{2} \mathrm{O}$ ) measured by microprobe analysis in the cytoplasm and yolk platelets of toad Bufo bufo oocytes freshly isolated in Ringer solution.

\begin{tabular}{|c|c|c|c|}
\hline \multirow[b]{2}{*}{$\begin{array}{l}\text { Cyto } \\
\text { plasm }\end{array}$} & \multirow[b]{2}{*}{$\begin{array}{l}\text { Cell diameter }{ }^{+} \\
(\mu \mathrm{m})\end{array}$} & \multicolumn{2}{|c|}{ Concentration in individual cells } \\
\hline & & $\begin{array}{l}\mathrm{Na} \\
\text { mean } \pm \text { S.E. }\end{array}$ & $\begin{array}{l}\mathrm{K} \\
\text { mean } \pm \mathrm{S} . \mathrm{E} .\end{array}$ \\
\hline 1 & 975 & $76.6 \pm 5.1(6)$ & $45.5 \pm 5.8(6)$ \\
\hline 2 & 957 & $89.1 \pm 14.5(5)$ & $107.7 \pm 5.1(5)$ \\
\hline 3 & 860 & $41.6 \pm 13.8(5)$ & $74.2 \pm 16.1(5)$ \\
\hline 4 & 874 & $51.0 \pm 6.8(5)$ & $73.7 \pm 4.1(5)$ \\
\hline Overall mean ${ }^{++}$ & & $64.6 \pm 4.8(21)$ & $75.3 \pm 5.5(21)$ \\
\hline \multicolumn{4}{|l|}{ Yolk } \\
\hline 1 & 975 & $178.7 \pm 22.9(6)$ & $335.6 \pm 26.5(6)$ \\
\hline 2 & 957 & $209.4 \pm 30.1(5)$ & $241.1 \pm 44.2(5)$ \\
\hline 3 & 860 & $39.9 \pm 12.7(5)$ & $263.7 \pm 35.1(5)$ \\
\hline 4 & 874 & $124.7 \pm 6.8(5)$ & $371.4 \pm 51.2(5)$ \\
\hline Overall mean $^{++}$ & & $138.2 \pm 16.2(21)$ & $303.0 \pm 13.3(21)$ \\
\hline
\end{tabular}

All concentrations in m-mole/l $\mathrm{H}_{2} \mathrm{O} \pm \mathrm{S}$.E. of mean (no. of observations).

+ Cell diameter was the mean of a batch of similar cells from which the measured cell was taken.

${ }^{++}$Calculated from all the concentration measurements from all cells taken together 


\section{DISCUSSION}

The present experiments show that the concentration of $\mathrm{Na}$ measured by microprobe analysis in fresh large oocytes (average diameter 1.4 $\mathrm{mm}$ ) is $82+7.3 \mathrm{~m}$-mole/l. $\mathrm{H}_{2} \mathrm{O}$ in cytoplasm, and $42 \pm 3.2 \mathrm{~m}$-mole $/ \mathrm{l} . \mathrm{H}_{2} \mathrm{O}$ in the nucleus. The cytoplasmic concentration agrees well with the previous figure of $88 \mathrm{~m}$-mole/l. $\mathrm{H}_{2} \mathrm{O}$ obtained for cytoplasmic $\mathrm{Na}$ in large Rana pipiens oocytes by NAORA, NAORA, IZAWA, ALLFREY and MIRSKY (22). It also agrees with the value of 83.6 obtained in the cytoplasm of Eurycea b. bilineata, 78.7 in Rana catesbiana and 74.8 in Desmognathus o. ochrophaeus oocytes (concentrations in m-mole/l. $\mathrm{H}_{2} \mathrm{O}$ ) by CENTURY, FENICHEL and HoROwITZ (5). The result on cytoplasmic $\mathrm{Na}$ is higher than the previous microprobe analysis result obtained by DICK (7) on toad Bufo bufo oocytes. The difference is probably mainly due to the use of larger cells in the present study which are known to have a high $\mathrm{Na}$ concentration (4).

The concentration of $\mathrm{Na}$ obtained in the nucleus in the present studies is $42 \mathrm{~m}$-mole/ 1 $\mathrm{H}_{2} \mathrm{O}$ which differs from some values previously obtained from the nucleus in various amphibian oocytes. Previous nuclear values in amphibian oocytes from investigations on isolated nuclei vary from 7.3 to $28 \mathrm{l} \mathrm{m}$-mole/ $/ \mathrm{H}_{2} \mathrm{O}(5,22,24)$. During isolation, materials may be lost from the nucleus, and materials from the cytoplasm may contaminate the nucleus. It seems likely that some very low levels of nuclear Na previously obtained from isolated nuclei were probably due to loss of the sodium during isolation, while the high levels resulted either from contamination with cytoplasm or from exposure of the nucleus during cell fractionation to extracellular fluids containing much sodium. JONES, JOHNSON, GUPTA and HALL (19) compared the $\mathrm{Na}$ data measured by microprobe analysis from sectioned nuclei with those from nuclei isolated from chick erythrocytes. The concentration of $\mathrm{Na}$ in isolated nuclei is variable, but in most cases, is increased up to 20 times the concentration in sectioned cells.

The value of nucleo/cytoplasmic ratio obtained from the present $\mathrm{Na}$ data is 0.51 . This finding is in qualitative agreement with other values obtained in large amphibian oocytes, i.e. in Rana pipiens 0.12 , in Rana catesbiana 0.21 (5) and in Triturus cristatus 0.84 (24).

A possible explanation for the asymmetry of $\mathrm{Na}$ concentration is probably due to a large, relatively immobile cytoplasmic $\mathrm{Na}$ fraction, sequestered in a special compartment. Another possible explanation for the asymmetry in $\mathrm{Na}$ concentration is the presence of $\mathrm{Na} / \mathrm{K}$ pump in the nuclear membrane similar to that in the cell membrane. Although little information is known about the active transport of Na across the nuclear membrane, SIEBERT et al. (25) reported that neither $\mathrm{Na}$ content nor isotopic $\mathrm{Na}^{+}$exchange in in vivo liver nuclei was affected by cooling or by metabolic inhibitors. The present experiments show that after treatment of oocytes with $\mathrm{Na} / \mathrm{K}$ pump inhibitors (ethacrynic acid or ouabain), Na concentrations increase and $\mathrm{K}$ concentrations decrease in both nucleus and cytoplasm. However, since the nuclear $\mathrm{Na}$ concentration increases in the case of ouabain which is known not to penetrate the cell membrane, and since the nuclear $\mathrm{K}$ level remains much higher than the cytoplasmic in the presence of inhibitors, it is unlikely that the nuclear electrolytes are maintained by an $\mathrm{Na} / \mathrm{K}$ pump in the nuclear membrane. However, these results do not entirely rule out the possibility of the presence of an $\mathrm{Na} / \mathrm{K}$ pump in the nuclear membrane.

Li-inexchangeable "sequestered" $\mathrm{Na}$. The concentrations of $\mathrm{Na}$ measured by microprobe analysis in oocytes exposed to Na-free Ringer solution ( $\mathrm{Li}$ - substituted for $\mathrm{Na}$ ) for 5 hours, $36.5 \pm 4.7 \mathrm{~m}$-mole/ $1 \mathrm{H}_{2} \mathrm{O}$ in cytoplasm, and $2.0 \pm 0.88 \mathrm{~m}$-mole $/ 1 \mathrm{H}_{2} \mathrm{O}$ in nucleus are lower than the concentrations obtained in fresh oocytes. The cytoplasmic/nuclear $(\mathrm{C} / \mathrm{N})$ ratio in fresh oocytes is 2.0 , whereas in oocytes exposed to Li-solution for 5 hours it is 18.3. The high $\mathrm{C} / \mathrm{N}$ ratio is probably due to the fact that most (if not all) the nuclear $\mathrm{Na}$ exchanges with external $\mathrm{Li}$, while only half the cytoplasmic $\mathrm{Na}$ exchanges with external $\mathrm{Li}$. The $\mathrm{C} / \mathrm{N}$ ratio obtained in the present experiments is higher than most of those obtained in previous studies on Li-exposed amphibian oocytes, which vary from 2.2 to 14.3 , but confirms previous studies which indicated the presence of an internal cytoplasmic fraction of $\mathrm{Na}$ in the oocyte which is 
inexchangeable (or very slowly exchangeable) with external $\mathrm{Li}(7,9,10,12,14)$.

The results of microprobe analysis on oocytes exposed to Li for 5 hours show that the amount of $\mathrm{Na}$ in the nucleus is $2.0 \mathrm{~m}$-mole $/ 1 \mathrm{H}_{2} \mathrm{O}$ which is $6 \%$ of the total inexchangeable $\mathrm{Na}$ in the oocyte. This value is in agreement with the value of less than 6\% reported by DiCK and FRY (9) in immature Bufo bufo oocytes and with the value of less than $5 \%$ reported by HoROwITZ and FENICHEL (15) in mature Eurycea oocytes.

The conclusion from our results that the Li-inexchangeable $\mathrm{Na}$ fraction in oocytes amounted to $40 \%$ of the total intracellular $\mathrm{Na}$ is reasonably compatible with the value previously obtained from immature Bufo bufo oocytes for the Li-inexchangeable $\mathrm{Na}$, i.e. kinetic results $(10-30 \%)(12),(13-62 \%)(8)$; autoradiographic results $(22 \%)(10)$; and activity coefficient results (50\%) (14).

Previous studies on mature Eurycea dislineata by Century, Fenichel and Horowitz (5), and HOROWITZ and FENICHEL (15), show two distinct kinetic fractions of $\mathrm{Na}$, a rapidly exchanging fraction comprising about $15 \%$ of the total cell $\mathrm{Na}$, and a large slowly exchanging fraction comprising the rest of cell $\mathrm{Na}$. HOROWITZ and FENICHEL (15) showed by autoradiography after loading with $\mathrm{Na}^{22}$ for 15000 sec that the fast exchanging fraction of nuclear $\mathrm{Na}$ is 1.3 times as concentrated as the cytoplasmic fast exchanging fraction measured per litre of water in nucleus and cytoplasm. Our results show that the Li-exchangeable $\mathrm{Na}$ in the nucleus is 0.87 times as concentrated as the cytoplasmic one. DiCK, FRY, JOHN and ROGERS (10) considered that the slowly exchanging and Li-inexchangeable fraction of $\mathrm{Na}$ are the same. The slowly exchanging fraction reported by Century, Fenichel and Horowitz (5) and HOROWITZ and FENICHEL (15) is similar in location to the Li-inexchangeable fraction reported in the present experiment, although its size is larger. These discrepancies are likely to be due to the different degrees of development of the oocytes used. CENTURY, FenICHEL and HOROWITZ (5), and HOROWITZ and FENICHEL (15), used mature oocytes which are known to have a high sequestered $\mathrm{Na}(12,23)$. Our estimation of the Li-inexchangeable $\mathrm{Na}$ (seques- tered $\mathrm{Na}$ ) is based on an average from 12 values, estimated from oocytes of different sizes, whose mean diameter ranged between $963-1966 \mu \mathrm{m}$. HoRowrTz et al. (16) by reference phase analysis found that in large salamander oocytes the activity coefficient of $\mathrm{Na}$ was 0.22 , i.e. that only $29 \%$ of cytoplasmic $\mathrm{Na}$ was free; the remaining $71 \%$ of cytoplasmic $\mathrm{Na}$ may correspond to $\mathrm{Li}$-inexchangeable $\mathrm{Na}$ but this is by no means certain.

The effect of ouabain and ethacrynic acid on the concentration of $\mathrm{Na}$ and $\mathrm{K}$ in the oocyte. Ouabain treatment of the oocytes caused an approximately $37 \%$ rise in the total Na concentration, consistent with the $50-60 \%$ inhibition of the Na pump by ouabain described in Bufo bufo oocytes by DICK and LEA (13). On the other hand, inhibition of the $\mathrm{Na}$ pump by ethacrynic acid results in $60 \%$ rise in total $\mathrm{Na}$ concentration, in agreement with the previous studies of BITTAR, DICK and FRY (3) who showed that ethacrynic acid is a potent inhibitor of $\mathrm{Na}$ pump.

The electrolyte levels in nuclei can be changed profoundly in intact oocytes by the inhibition of membrane-associated Na-K ATPase. Simultaneous treatment of oocytes with the inhibitors ouabain or ethacrynic acid result in massive increases in nuclear $\mathrm{Na}$, parallel with the increase in cytoplasmic $\mathrm{Na}$, to a level approaching (or exceeding) that of the cytoplasm. Our results suggest that the nuclear level of $\mathrm{Na}$ simply reflects the changes in cytoplasmic level, and is unlikely to be maintained by an Na pump present in the nuclear membrane. The present results agree qualitatively with the finding of JONES, JOHNSON, GUPTA and HALL (19) on frozen hydrated sections of chick red blood cells obtained from old embryos, which showed a great increase of $\mathrm{Na}$ and reduction in $\mathrm{K}$ levels, both in the cytoplasm and nucleus when erythrocytes were treated with ouabain and ethacrynic acid.

The important conclusion from $\mathrm{K}$ data is that the nuclear concentration is significantly higher than that of the cytoplasm in all solutions, so that the dominant nuclear cation is $\mathrm{K}$ rather than Na. The ratio of nuclear/cytoplasmic K concentration in fresh oocytes is 2.9 . This finding is in qualitative agreement with other values 
previously obtained in amphibian oocytes for the nuclear/cytoplasmic ratio for $\mathbf{K}$, i.e. in Bufo bufo 3.8 (7), in Rana pipiens 1.35 (5) and 2.43 (22), in Rana catesbiana 1.49 (5), and in Triturus cristatus $1.4-1.9$ (cells $900-1500 \mu \mathrm{m}$ in diameter) (24).

In view of the high nuclear $\mathrm{K}$ obtained in the present experiments it seems likely that either some of the nuclear $\mathrm{K}$ is bound to nuclear protein, or the high nuclear $\mathrm{K}$ level is due to an $\mathrm{Na} / \mathrm{K}$ pump present in the nuclear membrane which maintained the high $\mathrm{K}$ in the nucleus. After treatment of the oocytes with ouabain or ethacrynic acid, $\mathrm{K}$ concentrations decrease in both nucleus and cytoplasm. However, since the nuclear $K$ still remains much higher than the cytoplasmic in the presence of inhibitors, much of it is probably bound to protein rather than being retained by an $\mathrm{Na} / \mathrm{K}$ pump in the nuclear membrane. However, some nuclear $\mathrm{K}$ appears to be displaced by $\mathrm{Na}$ when the cytoplasmic $\mathrm{Na}$ rises.

By stereological analysis (18) it has recently been shown that the subcellular component whose volume fraction correlates most closely with the concentration of intracellular $\mathrm{Na}$ is the cytoplasmic vesicle, which appears to have a high $\mathrm{Na}$ concentration. These vesicles may be the site of the $\mathrm{Li}$-inexchangeable $\mathrm{Na}$ described in this paper. They may be involved in some way with $\mathrm{Na}$ transport in the oocyte, possibly by a process of exocytosis in accordance with the mechanism of $\mathrm{Na}$ transport in the oocyte proposed by DICK and FRY (9), or as described in frog skin by VOUTE et al. (28) and MOLlGARD and ROSTGAARD (20) and in choroid plexus by MOLLGARD and SAUNDERS (21). BESTERMAN et al. (2) have described a similar process of exocytosis in relation to sucrose transport in macrophages and fibroblasts.

\section{ACKNOWLEDGEMENTS}

D.A.T.DICK takes pleasure in acknowledging that the original inspiration for these studies began during the year 1958/59 which he spent as Carlsberg-Wellcome Research Fellow in the Physiological Department of the Carlsberg Laboratory working under the direction of Professor HEINZ HOLTER and in collaboration with Dr.

\section{Cicily ChapMan-ANDRESEN.}

We wish to thank Mrs. E. LLOYD-DAVIES and Mr. J. JAMES for assistance and advice with the electron microscope and Dr. A.Y. AL-HuBAITY for providing Figure 1. K.B. IBRAHIM was supported by a Research Scholarship from the Government of Iraq.

\section{REFERENCES}

1. Abelson, P.H. \& W.R. DURYeE: Radioactive sodium permeability and exchange in frogs eggs. Biol. Bull. 96, 205-217 (1949)

2. Besterman, J.M., J.A. Airhart, R.C. WoOdWORTH \& R.B. LOW: Exocytosis of pinocytosed fluid in cultured cells: kinetic evidence for rapid turnover and compartmentation. J. Cell Biol. 91, $716-727$ (1981)

3. BitTAR, E.E., D.A.T. Dick \& D.J. Fry: The action of ethacrynic acid on sodium efflux from single toad oocytes. J. Physiol., London, 196, 693-701 (1968)

4. CANNON, J.D., D.A.T. Dick \& D.O. Ho-YeN: Intracellular sodium and potassium concentrations in toad and frog oocytes during development. J. Physiol., London, 241, $497-508$ (1974)

5. Century, T.J., I.R. Fenichel \& S.B. Horowitz: The concentrations of water, sodium and potassium in the nucleus and cytoplasm of amphibian oocytes. J. Cell Sci. 7, 5-13 (1970)

6. Chandler, J.A: Quantitative X-ray microanalysis. In: Practical methods in electron microscopy, A.M. Glauert, ed., North Holland, Amsterdam, Vol. 5, Part II, pp. $471-494$ (1977)

7. Dick, D.A.T.: The distribution of sodium, potassium and chloride in the nucleus and cytoplasm of Bufo bufo oocytes measured by electron microprobe analysis. J. Physiol., London, 284, 37-53 (1978)

8. DiCK, D.A.T.\&.J.FRY: Location of inexchangeable sodium in the nucleus and cytoplasm of oocytes of Bufo bufo exposed to sodium-free solutions. J. Physiol., London, 231, 19-29 (1973)

9. Dick, D.A.T. \& D.J. Fry: Sodium fluxes in single amphibian oocytes: further studies and a new model. J. Physiol., London, 247, 91-116 (1975)

10. Dick, D.A.T., D.J. FRY, P.N. JoHN \& A.W. Rogers: Autoradiographic demonstration of inhomogeneous distribution of sodium in single oocytes of Bufo bufo. J. Physiol., London, 10, 305-319 (1970)

11. Dick, D.A.T.\& K.B. IBRAHIM: The effect of external ethacrynic acid and ouabain on the concentration and distribution of $\mathrm{Na}, \mathrm{K}$ and $\mathrm{Cl}$ in the amphibian oocyte measured by electron micro- 
K.B. IBRAHIM \& D.A.T. DiCK: $\mathrm{Na}$ and $\mathrm{K}$ in amphibian oocytes

probe X-ray analysis. J. Physiol., London, 296, 73P (1979)

12. Dick, D.A.T.\&E.J.A. LEA: Na fluxes in single toad oocytes with special reference to the effect of external and internal $\mathrm{Na}$ concentration on $\mathrm{Na}$ efflux. J. Physiol., London, 174, 55-90 (1964)

13. Dick, D.A.T.\& E.J.A. LEA: The partition of sodium fluxes in isolated toad oocytes. J. Physiol, London, 191, 289-308 (1967)

14. Dick, D.A.T. \& S.G.A. MCLAughlin: The activities and concentrations of sodium and potassium in toad oocytes. J. Physiol, London, 205, 61-78 (1969)

15. Horowitz, S.B. \& I.R. FENICHEL: Analysis of sodium transport in the amphibian oocyte by extractive and radioautographic techniques. J. Cell Biol. 47, 120-131 (1970)

16. Horowitz, S.B., P.L. Paine, L. Tluczek \& J.K. REYNHOUT: Reference phase analysis of free and bound intracellular solutes. 1 . Sodium and potassium in amphibian oocytes. Biophys. J. 25, 33-44 (1979)

17. IBRAHIM, K.B.: Estimation of sodium and potassium in yolk platelets of toad (Bufo bufo) oocytes by electron microprobe X-ray analysis. J. Physiol., London, 305, 91P (1980)

18. IвRAHIM, K.B. \& D.A.T. Dick: The distribution of sodium and potassium in toad (Bufo bufo) oocytes estimated by a stereological method. J. Microscopy 128, 95-105 (1982)

19. Jones, R.T., R.T. Johnson, B.L. Gupta \& T.A. HALL: The quantitative measurement of electrolyte elements in nuclei of maturing erythrocytes of chick embryo using electron-probe X-ray microanalysis. J. Cell Sci. 35, 67-85 (1979)

20. Mollgard, K. \& J. RostgaARD: Morphological aspects of some sodium transporting epithelia suggesting a transcellular pathway via the elements of the endoplasmic reticulum. J. Membrane Biol. $40,71-89(1978)$
21. Mollgard, K.\&N.R.SOUnders: A possible transepithelial pathway via endoplasmic reticulum in foetal sheep choroid plexus. Proc. R. Soc. B. 199 , 321-326 (1977)

22. NaOra, H., H. NaOra, M. Izawa, V.G. Allfrey \& A.E. MIRSKY: Some observations on differences in composition between the nucleus and cytoplasm of the frog oocyte. Proc. Nat. Acad. Sci. 48, 853-859 (1962)

23. Palmer, L.G., T.J. Century \& M.M. Civan: Activity coefficients of intracellular $\mathrm{Na}^{+}$and $\mathrm{K}^{+}$during development of frog oocytes. J. Membrane Biol. 40, 25-38 (1978)

24. RiemanN, W., C. Muir \& H.C. MacGregor: Sodium and potassium in oocytes of Triturus cristatus. J. Cell Sci. 4, 299-304 (1969)

25. Siebert, G. H. Langendorf, R. Hannover. D. Niz-Litzow, B.C. Pressman \& C. MoOre: Untersuchungen zur Rolle des Natrium-Stoffwechsels in Zellkern der Rattenleber. Hoppe-Seyler's Zeitschr. physiol. Chem., 343, 101-115 (1965)

26. Seveus, L.: Preparation of biological material for $\mathrm{X}$-ray microanalysis of diffusible elements. I. Rapid freezing of biological tissue in nitrogen slush and preparation of ultrathin frozen sections in the absence of trough liquid. J. Microsc. 112, 269-279 (1978)

27. SuMner, A.T.: Quantitation in bjological X-ray microanalysis, with particular reference to histochemistry. J. Microsc. 114, 19-30 (1978)

28. Voute, C.L., K. Mollgard \& H.H. Ussing: Quantitative relationship between active sodium transport, expansion of endoplasmic reticulum and specialised vacuoles ('scalloped sacs') in the outermost living cell layer of the frog skin epithelium (Rana temporaria). J. Membrane Biol. 21, 273-289 (1975)

29. Wallace, R.A.: Studies on amphibian yolk. III. A resolution of yolk platelet components. Biochim. Biophys. Acta, 74, 495-504 (1963) 